\title{
Improving Forecast Accuracy of Financial Vulnerability: Partial Least Squares Factor Model Approach
}

\author{
Hyeongwoo Kim*, Kyunghwan Ko**
}

The views expressed herein are those of the authors and do not necessarily reflect the official views of the Bank of Korea. When reporting or citing this paper, the authors' names should always be explicitly stated.

* Associate Professor, Department of Economics, Auburn University, Tel: +1-334-844-2928 Email: gmmkim@gmail.com

** Economist, Economic Research Team, Jeju Branch, The Bank of Korea, Tel: +82-64-720-2513

Email: kyunghwan.ko@bok.or.kr 


\section{Contents}

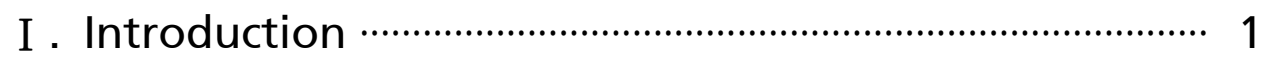

II . The Econometric Method ……..................................... 4

III. Empirical Findings ………………….......................... 10

IV . Concluding Remarks ……………………………..... 28

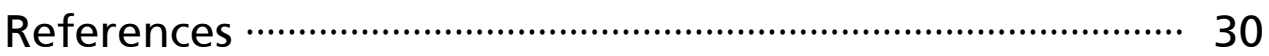




\section{Improving Forecast Accuracy of Financial Vulnerability: Partial Least Squares Factor Model Approach}

We present a factor augmented forecasting model for assessing the financial vulnerability in Korea. Dynamic factor models often extract latent common factors from a large panel of time series data via the method of the principal components (PC). Instead, we employ the partial least squares (PLS) method that estimates target specific common factors, utilizing covariances between predictors and the target variable. Applying PLS to 198 monthly frequency macroeconomic time series variables and the Bank of Korea's Financial Stress Index (KFSTI), our PLS factor augmented forecasting models consistently outperformed the random walk benchmark model in out-of-sample prediction exercises in all forecast horizons we considered. Our models also outperformed the autoregressive benchmark model in short-term forecast horizons. We expect our models would provide useful early warning signs of the emergence of systemic risks in Korea's financial markets.

Keywords: Partial least squares, Principal component analysis, Financial stress index, Out-of-sample forecast, RRMSPE, DMW statistics

JEL Classification: C38, C53, C55, E44, E47, G01, G17 


\section{I . Introduction}

Financial crises often come to a surprise realization with no systemic warnings. Furthermore, as Reinhart and Rogoff (2014) point out, harmful spillover effects on other sectors of the economy are likely to be severe because recessions followed by financial crises are often longer and deeper than other economic downturns. To avoid financial crises, Reinhart and Rogoff (2009) suggest to use an early-warning system (EWS) that alerts policy makers and financial market participants to incoming danger signs.

To design an EWS, it is crucially important to obtain a proper measure of the financial vulnerability that quantifies the potential risk in financial markets. One may consider the conventional Exchange Market Pressure (EMP) index proposed by Girton and Roper (1977). Instead, this paper employs an alternative measure known as financial stress index (FSTI) that is rapidly gaining popularity since the recent financial crisis.

The EMP index is computed using a small number of monetary variables such as exchange rate depreciations and changes in international reserves. On the other hand, FSTI is constructed utilizing a broad range of key financial market variables. In the US, 12 financial stress indices have currently become available (Oet, Eiben, Bianco, Gramlich, and Ong, 2011) since the recent financial crisis. The Bank of Korea also developed FSTI (KFSTI) in 2007 and started to report it on a yearly basis in their Financial Stability Report.

In this paper, we employ the monthly frequency KFSTI data as a proxy variable for financial market risk in Korea, and propose an out-of-sample forecasting procedure that extracts potentially useful predictive contents for KFSTI from a large panel of monthly frequency macroeconomic data. ${ }^{1)}$

Conventional approaches to predict financial crises include the following. Frankel and Saravelos (2012) and Sachs, Tornell, and Velasco (1996) used linear regression approaches to test the statistical significance of various economic variables on the occurrence of historical crisis episodes. Others employed

1) High frequency KFSTI data are for internal use only. We appreciate the Bank of Korea for giving permission to use the monthly frequency data. 
discrete choice models including parametric probit or logit models (Frankel and Rose, 1996; Eichengreen, Rose, and Wyplosz, 1995; Cipollini and Kapetanios, 2009) and nonparametric signals approach (Kaminsky, Lizondo, and Reinhart, 1998; Edison, 2003; EI-Shagi, Knedlik, and von Schweinitz, 2013; Christensen and $\mathrm{Li}, 2014)$.

Our forecasting procedure is different from these earlier studies in the sense that we extract potentially useful predictive contents for a new measure of the financial vulnerability such as the KFSTI from a broad range of macroeconomic time series data. Our proposed method is suitable in a data-rich environment, and may be considered as an alternative to dynamic factor models that are widely employed in the recent macroeconomic forecasting literature.

Since the influential work of Stock and Watson (2002), factor models often utilize principal components (PC) analysis to extract latent common factors from a large panel of predictor variables. Estimated factors, then, can be used to formulate forecasts of a target variable employing linear regressions of the target on estimated common factors. It should be noted that the PC method constructs common factors based solely on predictor variables.2) Boivin and $\mathrm{Ng}$ (2006), however, pointed out that the performance of the PC method may be poor in forecasting the target variable if predictive contents are in a certain factor that may be dominated by other factors.

To overcome this issue, we employ the partial least squares (PLS) method that is proposed by Wold (1982). The method constructs target specific common factors from linear, orthogonal combinations of predictor variables taking the covariance between the target variable and predictor variables into account. Even though Kelly and Pruitt (2015) demonstrate that PC and PLS generate asymptotically similar factors when the data has a strong factor structure, Groen and Kapetanios (2016) show that PLS models outperform PC-based models in forecasting the target variable in the presence of a weak factor structure.

In this paper, we estimate multiple common factors using PLS from a large panel of 198 monthly frequency macroeconomic data in Korea and the KFSTI

2) Cipollini and Kapetanios (2009) employed the dynamic factor model via the PC method for their out-of-sample forecasting exercises for financial crisis episodes. 
from October 2000 to June 2016. We apply PLS to the first differenced macroeconomic data and the KFSTI to avoid issues that are associated with nonstationarity in the data. ${ }^{3)}$ Then, we augment two types of benchmark models, the nonstationary random walk (RW) and the stationary autoregressive (AR) models, with estimated PLS factors to out-of-sample forecast the KFSTI foreign exchange market index (KFSTI-FX) and the KFSTI stock market index (KFSTI-Stock).

We evaluate the out-of-sample forecast accuracy of our PLS-based models relative to these benchmark models using the ratio of the root mean squared prediction errors (RRMSPE) and the Diebold-Mariano-West (DMW) test statistics. We employed both the recursive (expanding window) method and the fixed-size rolling window method. Based on the RRMSPE and the DMW statistics, our models consistently outperform the benchmark RW models in out-of-sample predictability in all forecast horizons we consider for up to one year. On the other hand, our models outperform the AR benchmark model only in short-term forecast horizons.

Financial market stability is viewed an important objective of many central banks. To the best of our knowledge, the present paper is the first to predict the emergence of systemic risks in financial markets in Korea using PLS-based dynamic factor models.4) We expect our models help provide useful early warning indicators of financial distress that may become prevalent in Korea's financial markets, resulting in harmful spillovers to other sectors of the economy.

The rest of the paper is organized as follows. Section 2 explains how we extract latent common factors and formulate out-of-sample forecasts using PLS factor-augmented forecasting models. We also describe our out-of-sample forecast strategies and model evaluation methods. In Section 3, we provide data descriptions and report our major empirical findings. Section 4 concludes.

3) Bai and $\mathrm{Ng}$ (2004) propose a similar method for their panel unit root test procedure that uses PC to estimate latent factors.

4) Kim, Shi, and Kim (2016) implemented similar forecasting exercises using factor estimates from the PC method, which utilizes 198 predictor variables but not the target variable. 


\section{The Econometric Method}

\section{The Method of the Principal Components}

Consider a panel of $\mathrm{N}$ macroeconomic time series predictor variables, $\mathrm{x}=\left[\mathrm{x}_{1}, \mathrm{x}_{2}, \cdots, \mathrm{x}_{N}\right]$, where $\mathrm{x}_{i}=\left[x_{i, 1}, x_{i, 2}, \cdots, x_{i, T}\right]^{\prime}, \quad i=1, \cdots, N$. Dynamic factor models that are based on the principal component (PC) method (e.g., Stock and Watson, 2002) assume the following factor structure for x. Abstracting from deterministic terms,

$$
x_{i, t}=\lambda_{i}^{\prime} \mathrm{f}{ }_{t}+\varepsilon_{i, t}
$$

where $\mathrm{f}_{t}=\left[f_{1, t}, f_{2, t}, \cdots, f_{R, t}\right]^{\prime}$ is an $R \times 1$ vector of latent common factors at time $t$ and $\lambda_{i}=\left[\lambda_{i, 1}, \lambda_{i, 2}, \cdots, \lambda_{i, R}\right]^{\prime}$ denotes an $R \times 1$ vector of time-invariant associated factor loading coefficients. $\varepsilon_{i, t}$ is the idiosyncratic error term.

As shown by Nelson and Plosser (1982), most macroeconomic time series variables are better approximated by a nonstationary stochastic process. Further, Bai and $\mathrm{Ng}$ (2004) pointed out that the PC estimator for $\mathrm{f}_{t}$ from (1) may be inconsistent when $\varepsilon_{i, t}$ is an integrated process. As Bai and Ng (2004) suggested, one may estimate $\mathrm{f}_{t}$ and $\lambda_{i}$ via the PC method for the first-differenced data. For this, rewrite (1) as follows.

$$
\Delta x_{i, t}=\lambda_{i}^{\prime} \Delta \mathrm{f}_{t}+\Delta \varepsilon_{i, t}
$$

for $t=2, \cdots, T$. After normalizing $\Delta \mathrm{x}=\left[\Delta \mathrm{x}_{1}, \Delta \mathrm{x}_{2}, \cdots, \Delta \mathrm{x}_{N}\right]$, we apply PC to $\Delta \mathrm{x} \Delta \mathrm{x}^{\prime}$ to obtain the factor estimates $\Delta \widehat{\mathrm{f}}_{t}$ along with their associated factor loading coefficients $\left.\hat{\lambda}_{i} \cdot 5\right)$ Estimates for the idiosyncratic components are naturally given by the residuals $\Delta \hat{\varepsilon}_{i, t}=\Delta x_{i, t}-\hat{\lambda}_{i}^{\prime} \Delta \hat{\mathrm{f}}_{t}$. Level variables are recovered as

5) We first normalize the data prior to estimations, because the method of the principal components is not scale invariant. 
follows,

$$
\hat{\varepsilon}_{i, t}=\sum_{s=2}^{t} \Delta \hat{\varepsilon}_{i, s}, \quad \widehat{\mathrm{f}}_{t}=\sum_{s=2}^{t} \Delta \widehat{\mathrm{f}}_{s}
$$

\section{The Partial Least Squares Method}

Partial least squares (PLS) models for a scalar target variable $y_{t}$ are motivated by the following linear regression model. Abstracting from deterministic terms,

$$
y_{t}=\Delta x_{t}^{\prime} \beta+u_{t}
$$

where $\Delta \mathrm{x}_{t}=\left[\Delta x_{1, t}, \Delta x_{2, t}, \cdots, \Delta x_{N, t}\right]^{\prime}$ is an $N \times 1$ vector of predictor variables at time $t=1, \cdots, T, \beta$ is an $N \times 1$ vector of associated coefficients, and $u_{t}$ is an error term. Note that we use the first-differenced predictor variables, assuming that $\mathrm{x}_{t}$ is a vector of integrated processes.

PLS models are useful especially when $N$ is large. Instead of running a regression for (4), one may employ a data dimensionality reduction method via the following regression with an $R \times 1$ vector of components $\Delta c_{t}=\left[\Delta c_{1, t}, \Delta c_{2, t}, \cdots \Delta c_{R, t}\right]^{\prime}, R<N$ as follows,

$$
\begin{aligned}
y_{t} & =\Delta \mathrm{x}_{t}^{\prime} \mathrm{w} \theta+u_{t} \\
& =\Delta c_{t}^{\prime} \mathrm{w} \theta+u_{t}
\end{aligned}
$$

That is,

$$
\Delta c_{t}=\mathrm{w}^{\prime} \Delta \mathrm{x}_{t},
$$

and $\quad \mathrm{w}=\left[\mathrm{w}_{1}, \mathrm{w}_{2}, \cdots, \mathrm{w}_{R}\right]$ is an $N \times R$ matrix of each column $\mathrm{W}_{r}=\left[w_{1, r}, w_{2, r}, \cdots w_{N, r}\right]^{\prime}, \quad r=1, \cdots, R$, is an $N \times 1$ vector of weights on predictor variables for the $r^{\text {th }}$ component or factor. $\theta$ is an $R \times 1$ vector of PLS regression coefficients. 
PLS regression minimizes the sum of squared residuals from the equation (5) for $\theta$ instead of $\beta$ in (4). It should be noted, however, that we do not directly utilize $\theta$ in the present paper. In what follows, we employ a two-step forecasting method so that our models are comparable with the PC-based forecasting models. That is, we estimate $\Delta c_{t}$ via the PLS method, then augment our benchmark forecasting model with PLS factor estimates for $\Delta c_{t}$.

There are many available PLS algorithms (Andersson, 2009) that work well. Among others, one may use the algorithm proposed by Helland (1990) to forecast the $j$-period ahead target variable $y_{t+j}, j=1,2, \cdots, k$. One may obtain these factors recursively as follows. First, $\Delta c_{1, t}$ is determined by the following linear combinations of the predictor variables in $\Delta \mathrm{x}_{t}$.

$$
\Delta \hat{c}_{i, t}=\sum_{i=1}^{N} w_{i, 1} \Delta x_{i, t},
$$

where the loading (weight) $w_{i, 1}$ is given by $\operatorname{Cov}\left(y_{t+j}, \Delta x_{i, t}\right)$.

Next, regress $y_{t+j}$ and $\Delta x_{i, t}$ on $\Delta \hat{c}_{1, t}$ to get residuals, $\tilde{y}_{t+j}$ and $\Delta \tilde{x}_{i, t}$, respectively. The second factor estimate $\Delta \hat{c}_{2, t}$ is then obtained similarly as in (7) with $w_{i, 2}=\operatorname{Cov}\left(\tilde{y}_{t+j}, \Delta \tilde{x}_{i, t}\right)$. We repeat until the $R^{t h}$ factor $\Delta \hat{c}_{R, t}$ is obtained.

\section{The PLS Factor Forecast Models}

Our first PLS factor forecast model, the PLS-RW model, is motivated by a nonstationary random walk process augmented by $\Delta \hat{c}_{t}$. Abstracting from deterministic terms,

$$
y_{t+j}^{P L S_{R W}}=y_{t}+\gamma_{j}^{\prime} \Delta \hat{c}_{t}+e_{t+j}, \quad j=1,2, \cdots, k,
$$

that is, when $\gamma_{j}=0, y_{t}$ obeys the random walk (RW) process.

Since the coefficient on $y_{t}$ is fixed, we cannot use the unrestricted least squares estimator for (8). We resolve this problem by regressing $y_{t+j}-y_{t}$ on 
$\Delta \hat{c}_{t}$ first to obtain the consistent estimate $\hat{\gamma}_{j}$. ${ }^{6}$ ) Adding $y_{t}$ back to the fitted value, we obtain the following $j$-period ahead forecast for $y_{t+j}$,

$$
\hat{y}_{t+j \mid t}^{P L S_{R W}}=y_{t}+\hat{\gamma}_{j}^{\prime} \Delta \hat{c}_{t}
$$

The natural benchmark (BM) model of the PLS-RW model (8) is the following RW model.

$$
y_{t+1}^{B M_{R W}}=y_{t}+\eta_{t+1},
$$

where $e_{t+j}$ in (9) is a partial sum of the white noise process $\eta_{t}$, that is, $e_{t+j}=$ $\sum_{s=1}^{j} \eta_{t+s}$. It should be noted that our PLS-RW model (8) nests this RW benchmark model (10) when $\gamma_{j}=0$. The $j$-period ahead forecast from this benchmark RW model is,

$$
\hat{y}_{t+j \mid t}^{B M_{R W}}=y_{t}
$$

Our second PLS factor forecast model, the PLS-AR model, is motivated by a stationary $\mathrm{AR}(1)$-type stochastic process augmented by PLS factor estimates $\Delta \hat{c}_{t}$. Abstracting from deterministic terms,

$$
y_{t+j}^{P L S_{A R}}=\alpha_{j} y_{t}+\beta_{j}^{\prime} \Delta \hat{c}_{t}+u_{t+j}, \quad j=1,2, \cdots, k,
$$

where $\alpha_{j}$ is less than one in absolute value for stationarity.

We again employ a direct forecasting approach by regressing the $j$-period ahead target variable $\left(y_{t+j}\right)$ directly on the current period target variable $\left(y_{t}\right)$ and the estimated factors $\left(\Delta \hat{c}_{t}\right)$. Note that (12) is an AR (1) process for $j=1$

6) That is, we assume that $y_{t+j}-y_{t}$ is stationary. 
extended by covariates $\Delta \hat{c}_{t}$. Applying the ordinary least squares (LS) estimator for (12), we obtain the following $j$-period ahead forecast for the target variable,

$$
\hat{y}_{t+j \mid t}^{P L S_{A R}}=\hat{\alpha}_{j} y_{t}+\hat{\beta}_{j}^{\prime} \Delta \hat{c}_{t}
$$

where $\hat{\alpha}_{j}$ and $\hat{\beta}_{j}$ are the least squares coefficient estimates.

Naturally, the benchmark model for the PLS-AR (12) is the following stationary AR(1)-type or simply the AR model,

$$
y_{t+j}^{B M_{A R}}=\alpha_{j} y_{t}+u_{t+j}, \quad j=1,2, \cdots, k,
$$

which relates $y_{t+j}$ directly with the current value $y_{t}$. The $j$-period ahead forecast from this model is,

$$
\hat{y}_{t+j}^{B M_{A R}}=\hat{\alpha}_{j} y_{t},
$$

where $\hat{\alpha}_{j}$ is obtained by regressing $y_{t+j}$ directly on $y_{t}$ as in (14).7) Note that the PLS-AR model (12) nests the stationary benchmark model (14) when $\Delta \hat{c}_{t}$ does not contain any useful predictive contents for $y_{t+j}$, that is, $\beta_{j}=0$.

\section{Out-of-Sample Forecast Strategies}

We first implement out-of-sample forecast exercises employing a recursive (expanding window) scheme. After estimating PLS factors $\{\Delta \hat{c}\}_{t=1}^{T_{0}}$ using the initial $T_{0}<T$ observations, $\left\{y_{t}, \Delta x_{i, t}\right\}_{t=1}^{T_{0}}, i=1,2, \cdots, N$, we obtain the $j$-period ahead out-of-sample forecast for the target variable, $y_{T_{0}+j}$ by (9) or (13). Then, we expand the data by adding one more observation,

7) One may employ a recursive approach with an $\mathrm{AR}$ (1) model, $y_{t+j}=\alpha y_{t}+\varepsilon_{t+1}$. Given the estimate of the persistence parameter, one may formulate the j-period ahead forecast by $\hat{\alpha}^{j} y_{t}$. 
$\left\{y_{t}, \Delta x_{i, t}\right\}_{t=1}^{T_{0}+1}, \quad I=1,2, \cdots, N$, and re-estimate $\{\Delta \hat{c}\}_{t=1}^{T_{0}+1}$ which is used to formulate the next forecast, $y_{T_{0}+j+1}$. We repeat this until we forecast the last observation, $y_{T}$. We implement forecasting exercises under this expanding window scheme for up to 12-month forecast horizons, $j=1,2, \cdots, 12$.

We also employ a fixed-size rolling window method, which performs better than the recursive method in the presence of structural breaks. After we obtain the first forecast $y_{T_{0}+j}$ using the initial $T_{0}<T$ observations, $\left\{y_{t}, \Delta x_{i, t}\right\}_{t=1}^{T_{0}}$, $i=1,2, \cdots, N$, we add one observation but drop one earliest observation for the next round forecasting.

That is, we re-estimate $\{\Delta \hat{c}\}_{t=2}^{T_{0}+1}$ from $\left\{y_{t}, \Delta x_{i, t}\right\}_{t=2}^{T_{0}+1}, \quad j=1,2, \cdots, N$, maintaining the same number of observations $\left(T_{0}\right)$ to obtain the second round forecast, $y_{T_{0}+j+1}$. Again, we repeat until we forecast the last observation, $y_{T}$.

For model evaluations regarding the out-of-sample prediction accuracy, we use the ratio of the root mean square prediction error (RRMSPE) defined as follows,

$$
\operatorname{RRMSPE}(j)=\frac{\sqrt{\frac{1}{T-T_{0}-J} \Sigma_{t+T_{0}+j}^{T}\left(\varepsilon_{t+j \mid t}^{P L S_{m}}\right)^{2}}}{\sqrt{\frac{1}{T-T_{0}-J} \Sigma_{t+T_{0}+j}^{T}\left(\varepsilon_{t+j \mid t}^{B M_{m}}\right)^{2}}}, m=A R, R W
$$

where

$$
\varepsilon_{t+j \mid t}^{B M_{m}}=y_{t+j}-\hat{y}_{t+j \mid t}^{B M_{m}}, \quad \varepsilon_{t+j \mid t}^{P L S_{m}}=y_{t+j}-\hat{y}_{t+j \mid t}^{P L S_{m}}
$$

Note that our PLS models outperform the benchmark models when RRMSPE is greater than 1 .

We supplement our analyses by employing the Diebold-Mariano-West (DMW) test. For this, we define the following loss differential function, 


$$
d_{t}=\left(\begin{array}{c}
B M_{m} \\
\varepsilon_{t+j \mid t}
\end{array}\right)^{2}-\left(\begin{array}{c}
P L S_{m} \\
\varepsilon_{t+j \mid t}
\end{array}\right)^{2}, m=1,2
$$

where the squared loss function can be replaced with the absolute value loss function.

The $D M W$ statistic is defined as follows to test the null of equal predictive accuracy, that is, $H_{0}: E d_{t}=0$,

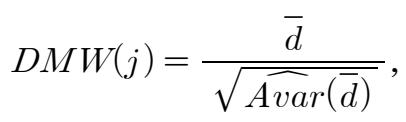

where $\bar{d}$ is the sample average, $\bar{d}=\frac{1}{T-T_{0}-j} \Sigma_{t=T_{0}+j}^{T} d_{t}$. In the presence of serial correlations, $\widehat{\operatorname{Ava}}(\bar{d})$ denotes the long-run variance of $\bar{d}$,

$$
\widehat{\operatorname{Avar}}(\bar{d})=\frac{1}{T-T_{0}} \sum_{i=-q}^{q} k(i, q) \hat{\Gamma}_{i}
$$

where $k(\cdot)$ is a kernel function with the bandwidth parameter $q$, and $\hat{\Gamma}_{i}$ is the $i^{\text {th }}$ autocovariance function estimate.

\section{Empirical Findings}

\section{Data Descriptions}

We employ the financial stress index (KFSTI) data to quantify the financial vulnerability in Korea. The Bank of Korea introduced the index in 2007 and report KFSTI on a yearly basis in their Financial Stability Report. We obtained monthly frequency data, which in principle are for internal use only. ${ }^{8)}$ The data is available from May 1995, but our sample period covers from October 2000 until August 2016 to obtain a large panel of predictor variables.

8) We obtained permission from the Bank of Korea to use the data for this research. 
Figure 1: Korean Financial Stress Index
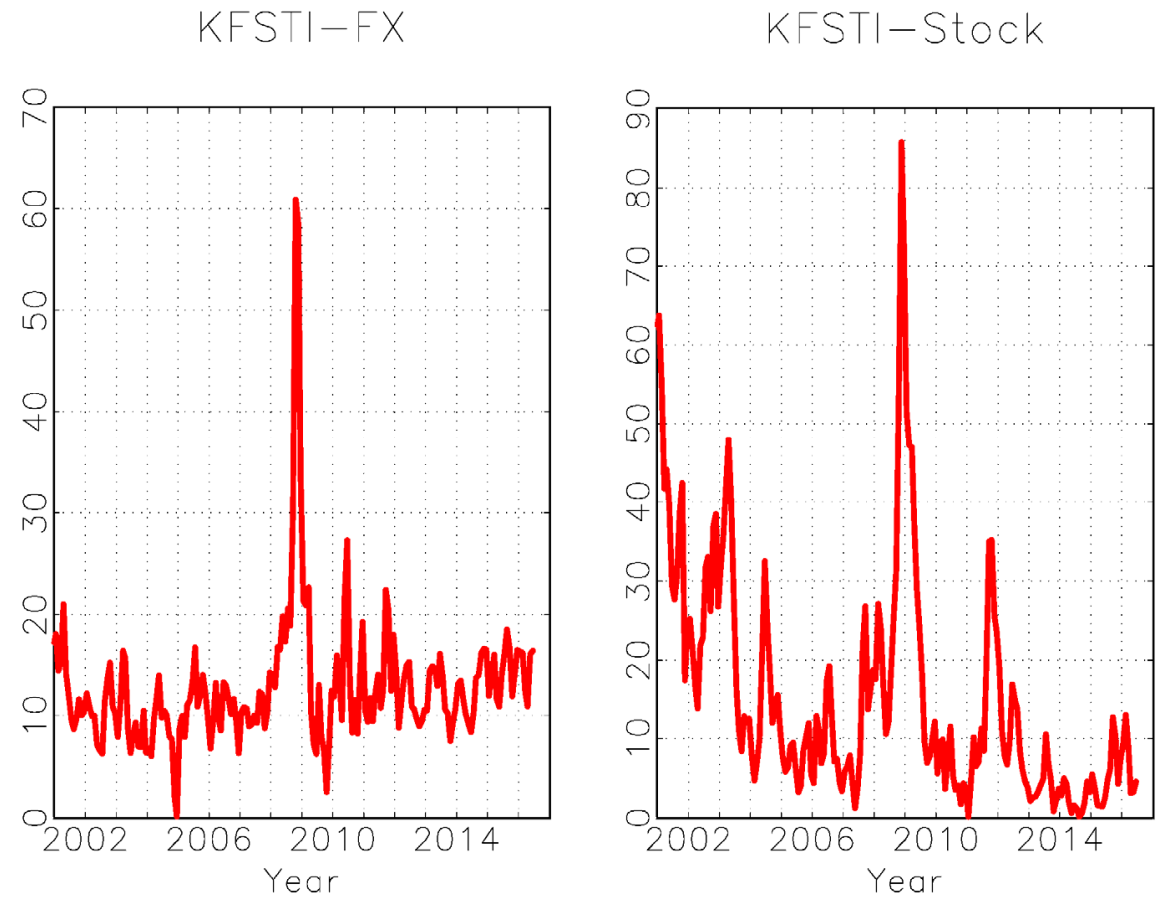

We use the following two KFSTI sub-indices, one for the foreign exchange market (KFSTI-FX) and the other one for the stock market (KFSTI-Stock). We do not report forecasting exercise results for the two other KFSTI sub-indices for the bond market and for the financial industry, since not only our PLS factor models but also PC models performed relatively poorly for these two indices. That is, these sub- indices seems to be somewhat disconnected from the common factor estimates in the present paper. Put it differently, such limited performances of our factor models might be due to the fact that our common factors are extracted from macroeconomic predictor variables even though the financial industries and bond markets are often influenced by non-economic political factors.

Figure 1 provides graphs of the KFSTI-FX and the KFSTI-Stock. We note that both indices exhibit a sharp spike during the recent financial crisis that 


\section{Table 1: Macroeconomic Data Descriptions}

\begin{tabular}{lll} 
Group ID & Data ID & Data Descriptions \\
$\# 1$ & $1-14$ & Domestic and World Interest Rates \\
$\# 2$ & $15-35$ & Exports/mports Prices \\
$\# 3$ & $36-54$ & Producer/Consumer/Housing Prices \\
$\# 4$ & $55-71$ & Monetary Aggregates \\
$\# 5$ & $72-83$ & Bilateral Exchange Rates \\
$\# 6$ & $84-110$ & Manufacturers'/Construction New Orders \\
$\# 7$ & $111-117$ & Manufacturers' Inventory Indices \\
$\# 8$ & $118-135$ & Housing Inventories \\
$\# 9$ & $136-157$ & Sales and Capacity Utilizations \\
$\# 10$ & $158-171$ & Unemployment/Employment/Labor Force Participation \\
$\# 11$ & $172-180$ & Industrial Production Indices \\
$\# 12$ & $181-186$ & Business Condition Indices \\
$\# 13$ & $187-198$ & Stock Indices \\
\hline
\end{tabular}

began in 2008. KFSTI-Stock exhibits more frequent turbulent periods in comparison with dynamics of the KFSTI-FX.

We obtained 198 predictor variables from the Bank of Korea. Observations are monthly frequency and span from October 2000 to August 2016. All variables other than those in percent (e.g., interest rates and unemployment rates) are log-transformed prior to estimations. We categorized these 198 time series data into 13 groups as summarized in Table 1.

Group \#1 includes 14 domestic and world nominal interest rates. Groups \#2 through \#4 are an array of prices and monetary aggregate variables, while group \#5 consist of bilateral nominal exchange rates. That is, groups \#1 through \#5 represent nominal sector variables in Korea. On the other hand, groups \#6 through \#11 entail various kinds of real activity variables such as production, inventory, and labor market variables. The last two groups represent business condition indices and stock market indices in Korea, respectively.

\section{Evaluations of the Model}

This subsection discusses the in-sample fit and the out-of-sample prediction performance of our PLS factor models relative to those of the benchmark and PC factor models. 


\subsection{In-Sample Fit Analysis}

Figure 2 reports estimated level PC factors, $\widehat{\mathrm{f}}_{t}=\Sigma_{s=2}^{t} \Delta \widehat{\mathrm{f}}_{s}$, for up to 6 factors, along with their associated factor loading coefficient estimates $(\hat{\lambda})$. In Figure 3 and Figure 4, we report level PLS factors $\hat{c}_{t}=\Sigma_{s=2}^{t} \Delta \hat{c}_{s}$ for the KFSTI-FX and the KFSTI-Stock, respectively, and their weight matrix estimates $(\widehat{\mathrm{w}})$. Note that we report two sets of PLS factors whereas only one set of PC factors is presented. This is because the PLS method utilizes the covariance between the predictor variables and the target variable, whereas the PC method does not consider the target variable when it extracts the common factors.

We noticed that PC factors are very different from PLS factors for each KFSTI index. Further, we note that $\hat{\lambda}$ estimates are very different from $\widehat{w}$, meaning that PLS and PC factor estimates are obtained from utilizing different combinations of the predictor variables $\mathrm{x}$. Since we are mainly interested in out-of-sample predictability performances of the PLS method relative other models, we do not attempt to trace the sources of these factors. However, distinct factor estimates from the PLS and the PC methods imply that the performance of these methods would differ in out-of-sample forecasting exercises we report in what follows.

We also report $R^{2}$ values in Figure 5, obtained from LS regressions of the target variable $y_{t}$ on estimated factors, $\Delta \hat{c}_{t}$ and $\Delta \widehat{\mathrm{f}}_{t}$, for up to 12 factors. Not surprisingly, PLS factors provide much better in-sample fit performance than PC factors, because $\Delta \hat{c}_{t}$ is estimated using the covariance between the target and the predictor variables. For example, $R^{2}$ from $\Delta \hat{c}_{1}$ is over 0.3 , whereas that from $\Delta \hat{f}_{1}$ is slightly over 0.02 for the KFSTI-FX. In the case of the KFSTI-Stock, $R^{2}$ from $\Delta \hat{c}_{1}$ is about 0.2 , while $\Delta \hat{f}_{1}$ virtually has no explanatory power. 
Figure 2: Principal Component Analysis
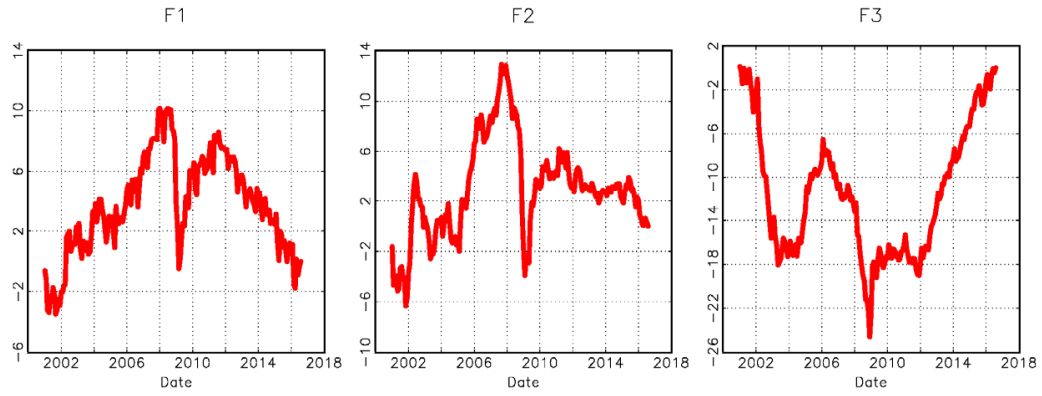

F4

F5
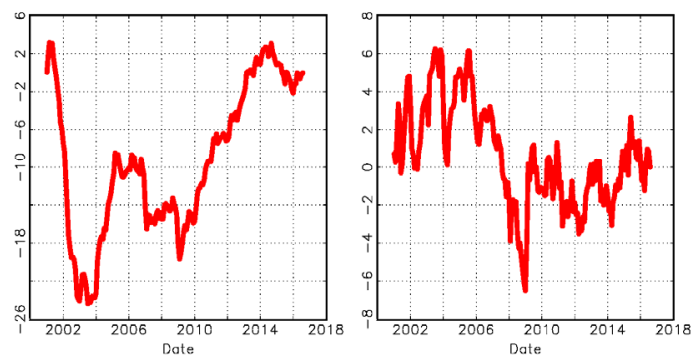

F6

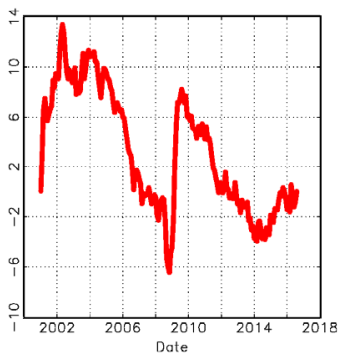

$\Delta \mathrm{F} 1$

$\triangle \mathrm{F} 2$

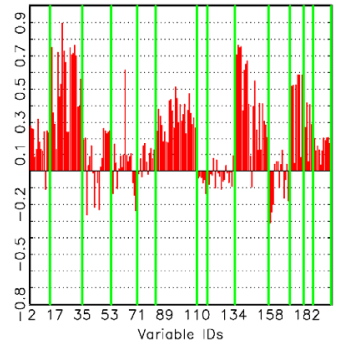

$\triangle \mathrm{F} 4$

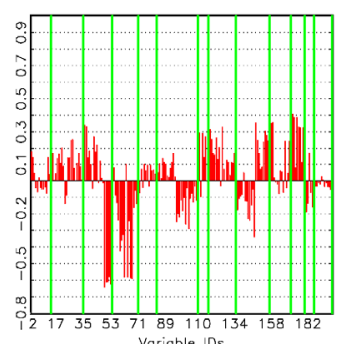

Variable IDs

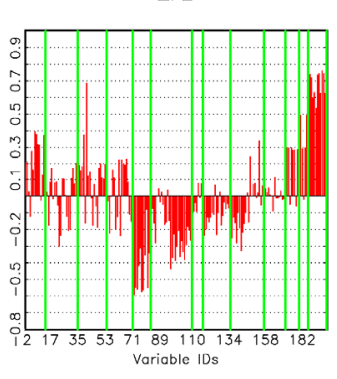

$\triangle \mathrm{F} 3$

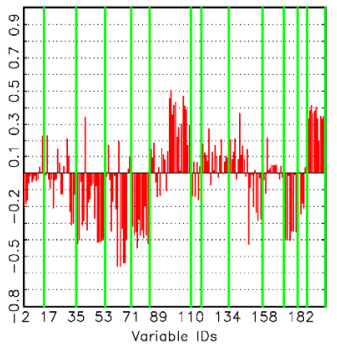

$\triangle \mathrm{FG}$
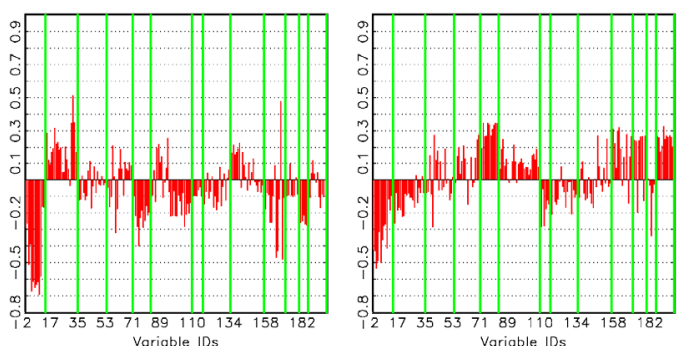

Variable $1 \mathrm{Ds}$

Note: Estimated level factors via the method of the principal component are reported in the top panel. Graphs in the bottom panel are factor loading coefficients estimates. 
Figure 3: Partial Least Squares Estimation: Foreign Exchange Market

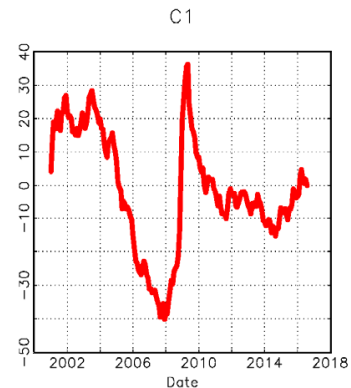

C 4

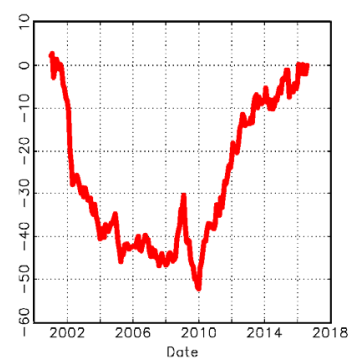

$\triangle \mathrm{C} 1$

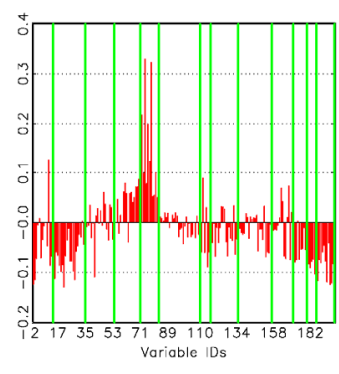

$\triangle \mathrm{C} 4$

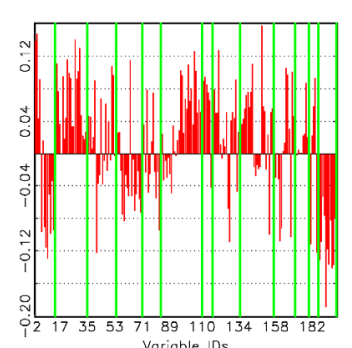

Variable IDs

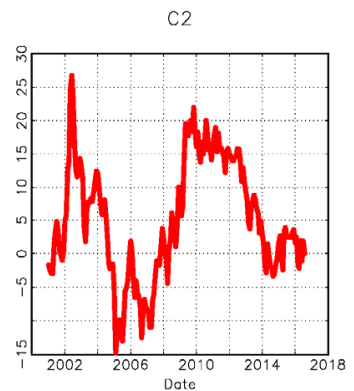

C5

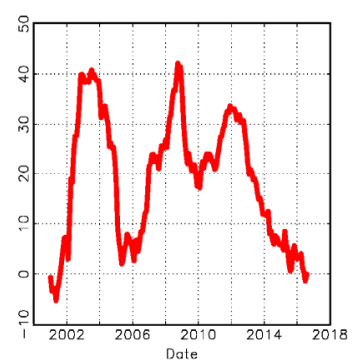

$\triangle C_{2}$

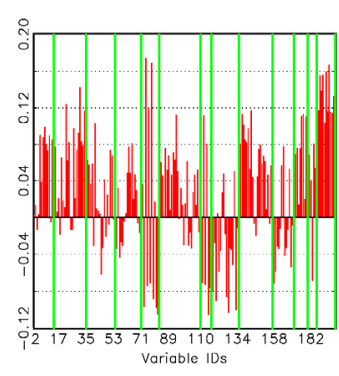

$\triangle \mathrm{C} 5$

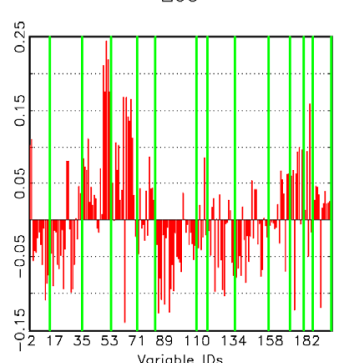

C3

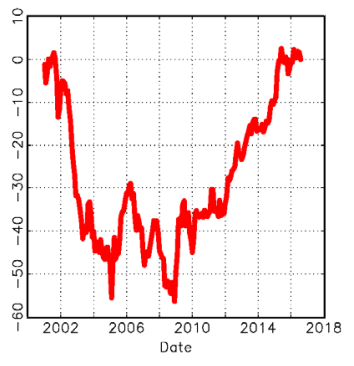

C6

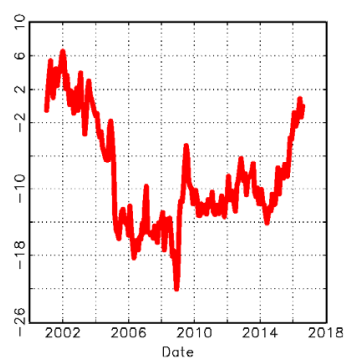

$\triangle \mathrm{C} 3$

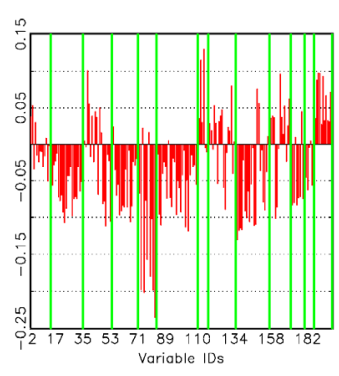

$\triangle \mathrm{C} 6$

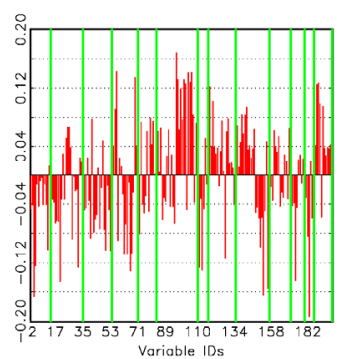

Note: Estimated level factors via the partial least squares method are reported in the top panel. Graphs in the bottom panel are weighting matrix estimates. 
Figure 4: Partial Least Squares Estimation: Stock Market

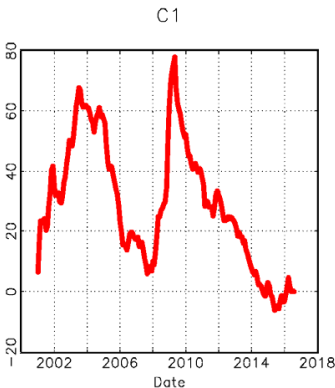

C4

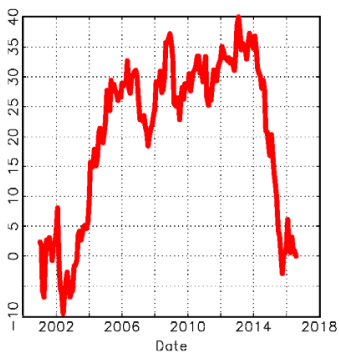

$\triangle \mathrm{C} 1$

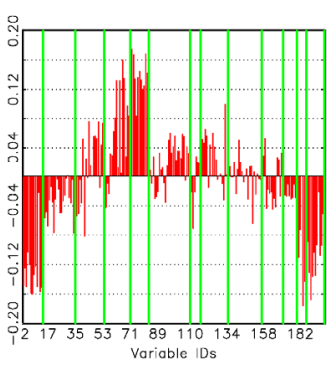

$\triangle \mathrm{C} 4$

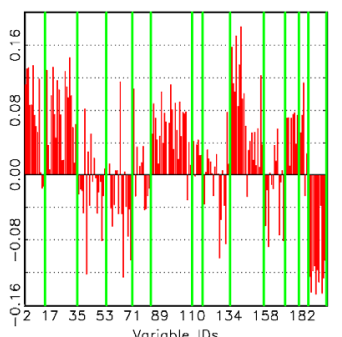

Variable IDs

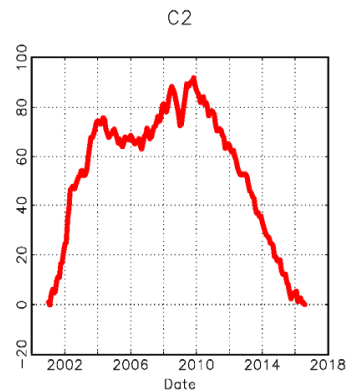

C5

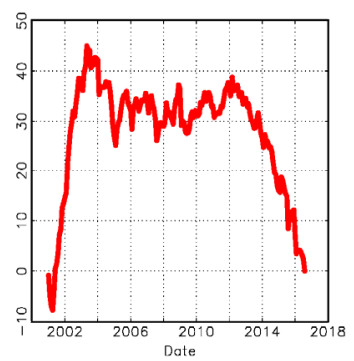

$\triangle \mathrm{C} 2$

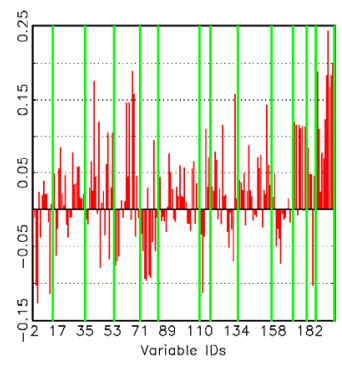

$\triangle \mathrm{CS}$

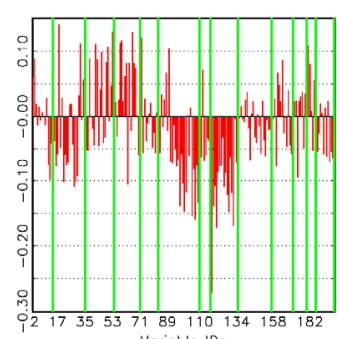

C3

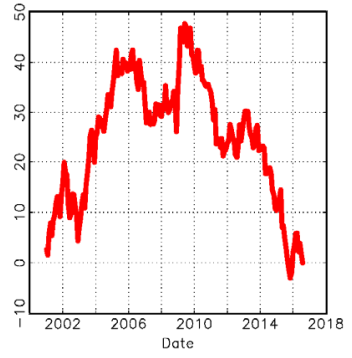

C6

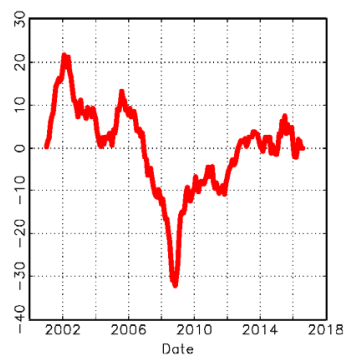

$\triangle \mathrm{C} 3$

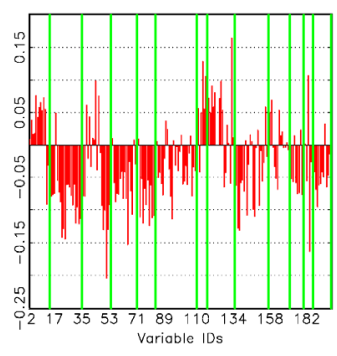

$\triangle \mathrm{C} 6$

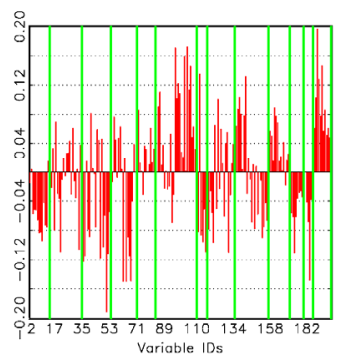

Note: Estimated level factors via the partial least squares method are reported in the top panel. Graphs in the bottom panel are weighting matrix estimates. 
Figure 5: In-Sample Fit Analysis: R Squares
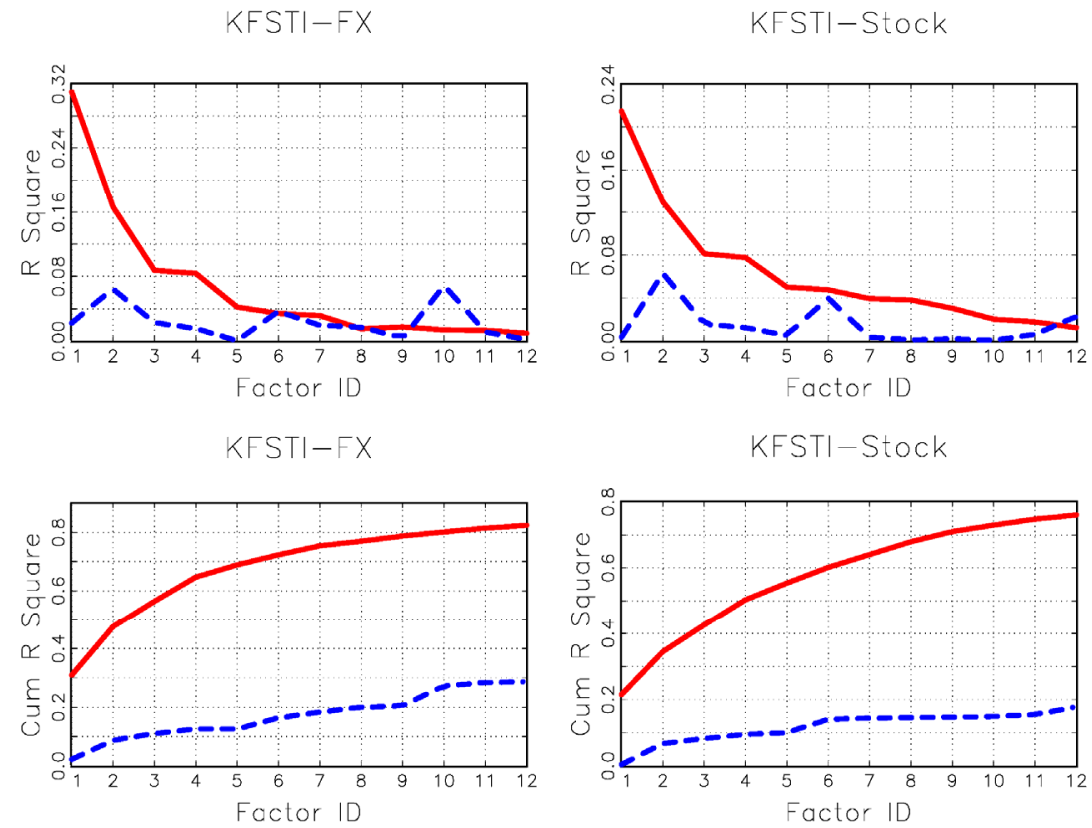

Note: We report $R^{2}$ and cumulative $R^{2}$ values in the top and lower panel, respectively.

Note that $\Delta \hat{f}_{10}$ and $\Delta \hat{f}_{2}$ have the highest $R^{2}$ for the KFSTI-FX and for the KFSTI-Stock, respectively, whereas contributions of PLS factors are the highest for the first factor estimate $\Delta \hat{c}_{1}$. That is, marginal $R^{2}$ decreases when we regress the target variable to the next PLS factors. This is because we extract orthogonal PLS factors sequentially, utilizing the remaining covariances of the target and the predictor variables. Since the PC method uses only the predictor variables without considering the target variable, marginal $R^{2}$ values do not necessarily decrease. Cumulative $R^{2}$ value with up to 12 PLS factors is about 0.8 for both indices, whereas that with PC factors is less than 0.3 and 0.2 for the foreign exchange index and the stock index, respectively. In a nutshell, the PLS method yields superior in-sample fit performance in comparison with the PC method. 


\section{Table 2: PLS-RW vs. RW: Foreign Exchange Market}

\begin{tabular}{|c|c|c|c|c|c|c|c|c|c|c|c|}
\hline \multirow[b]{2}{*}{$k$} & \multirow[b]{2}{*}{$h$} & \multicolumn{2}{|c|}{ Recursive } & \multicolumn{2}{|c|}{ Rolling Window } & \multirow[b]{2}{*}{$k$} & \multirow[b]{2}{*}{$h$} & \multicolumn{2}{|c|}{ Recursive } & \multicolumn{2}{|c|}{ Rolling Window } \\
\hline & & RRMSPE & $D M W$ & RRMSPE & $D M W$ & & & RRMSPE & $D M W$ & RRMSPE & $D M W$ \\
\hline \multirow[t]{6}{*}{1} & 1 & 0.924 & -1.447 & 1.028 & 1.327 & 6 & 1 & 0.993 & -0.090 & 1.057 & 1.306 \\
\hline & 2 & 1.006 & 0.130 & 1.052 & 1.854 & & 2 & 1.040 & 0.416 & 1.090 & 2.014 \\
\hline & 4 & 1.030 & 0.498 & 1.047 & 1.607 & & 4 & 1.172 & 1.548 & 1.145 & 3.485 \\
\hline & 6 & 1.157 & 1.166 & 1.056 & 1.340 & & 6 & 1.336 & 2.188 & 1.201 & 3.386 \\
\hline & 9 & 1.291 & 3.760 & 1.050 & 1.278 & & 9 & 1.328 & 3.126 & 1.151 & 2.753 \\
\hline & 12 & 1.377 & 2.142 & 1.046 & 0.959 & & 12 & 1.544 & 2.012 & 1.155 & 2.657 \\
\hline \multirow[t]{6}{*}{2} & 1 & 0.960 & -0.558 & 1.019 & 0.806 & 8 & 1 & 0.985 & -0.171 & 1.084 & 2.556 \\
\hline & 2 & 0.990 & -0.143 & 0.979 & -0.485 & & 2 & 1.049 & 0.462 & 1.088 & 1.667 \\
\hline & 4 & 1.086 & 1.093 & 1.035 & 1.032 & & 4 & 1.238 & 1.999 & 1.196 & 3.536 \\
\hline & 6 & 1.159 & 1.360 & 1.056 & 1.551 & & 6 & 1.295 & 1.956 & 1.169 & 3.081 \\
\hline & 9 & 1.215 & 3.008 & 1.052 & 1.303 & & 9 & 1.356 & 3.978 & 1.217 & 3.783 \\
\hline & 12 & 1.360 & 2.276 & 1.060 & 1.193 & & 12 & 1.470 & 2.016 & 1.189 & 2.949 \\
\hline \multirow[t]{6}{*}{4} & 1 & 0.964 & -0.456 & 1.033 & 0.640 & 10 & 1 & 0.992 & -0.092 & 1.038 & 0.972 \\
\hline & 2 & 1.031 & 0.382 & 1.059 & 1.363 & & 2 & 1.077 & 0.708 & 1.055 & 0.929 \\
\hline & 4 & 1.111 & 1.184 & 1.128 & 3.594 & & 4 & 1.290 & 2.241 & 1.135 & 1.803 \\
\hline & 6 & 1.281 & 2.139 & 1.213 & 3.176 & & 6 & 1.330 & 2.149 & 1.072 & 1.259 \\
\hline & 9 & 1.337 & 4.173 & 1.171 & 3.116 & & 9 & 1.356 & 3.626 & 1.182 & 3.059 \\
\hline & 12 & 1.550 & 2.281 & 1.132 & 2.395 & & 12 & 1.572 & 2.391 & 1.213 & 2.990 \\
\hline
\end{tabular}

Note: RRMSPE denotes the ratio of the root mean squared prediction errors, which is the mean squared prediction error (RMSPE) from the benchmark model divided by the RMSPE from the competing Partial Least Squares factor model. DMW is the Diebold-Mariano-West statistics. We repeat estimations and forecasting starting from the first $50 \%$ observations until we (out-of-sample) forecast the last observation of the KFSTI. DMW statistics in bold denote the rejection of the null hypothesis of equal predictability at the $5 \%$ significance level in favor of our factor models. The critical values are from McCracken (2007) to avoid size distortion because the benchmark model is nested by our factor model.

\subsection{Out-of-Sample Forecasting Performance}

In Table 2 and Table 3, we report RRMSPEs and the DMW statistics of the PLS-RW forecasting model (9) relative to the performance of the RW benchmark model (11) for the KFSTI-FX and the KFSTI-Stock, respectively. We implement out-of-sample forecast exercises using up to $12(k)$ factor estimates obtained from PLS for $\left\{y_{t+j}, \Delta x_{i, t}\right\}$ for up to 12-month forecast horizons $(h)$. We used $p_{50 \%}$ for the sample split point, that is, initial $50 \%$ observations were used to formulate the first out-of-sample forecast in implementing forecasting exercises via the recursive (expanding window) scheme as well as the fixed-size rolling window scheme. 
Table 3: PLS-RW vs. RW: Stock Market

\begin{tabular}{|c|c|c|c|c|c|c|c|c|c|c|c|}
\hline \multirow[b]{2}{*}{$k$} & \multirow[b]{2}{*}{$h$} & \multicolumn{2}{|c|}{ Recursive } & \multicolumn{2}{|c|}{ Rolling Window } & \multirow[b]{2}{*}{$k$} & \multirow[b]{2}{*}{$h$} & \multicolumn{2}{|c|}{ Recursive } & \multicolumn{2}{|c|}{ Rolling Window } \\
\hline & & RRMSPE & $D M W$ & RRMSPE & $D M W$ & & & RRMSPE & $D M W$ & RRMSPE & $D M W$ \\
\hline \multirow[t]{6}{*}{1} & 1 & 0.992 & -1.241 & 0.993 & -3.170 & 6 & 1 & 1.045 & 1.227 & 1.127 & 3.155 \\
\hline & 2 & 0.992 & -0.980 & 1.009 & 0.933 & & 2 & 1.078 & 1.242 & 1.271 & 3.553 \\
\hline & 4 & 0.992 & -0.544 & 1.010 & 0.730 & & 4 & 1.111 & 1.763 & 1.334 & 3.175 \\
\hline & 6 & 1.016 & 0.888 & 1.003 & 0.190 & & 6 & 1.107 & 2.038 & 1.333 & 3.277 \\
\hline & 9 & 1.024 & 0.703 & 1.007 & 0.244 & & 9 & 1.114 & 1.245 & 1.341 & 2.697 \\
\hline & 12 & 1.017 & 0.610 & 1.010 & 0.381 & & 12 & 1.107 & 1.836 & 1.338 & 3.240 \\
\hline \multirow[t]{6}{*}{2} & 1 & 1.020 & 1.362 & 1.058 & 2.802 & 8 & 1 & 1.052 & 1.249 & 1.137 & 2.891 \\
\hline & 2 & 1.019 & 0.765 & 1.089 & 2.423 & & 2 & 1.064 & 0.932 & 1.282 & 3.194 \\
\hline & 4 & 1.015 & 0.571 & 1.128 & 2.775 & & 4 & 1.104 & 1.550 & 1.317 & 3.004 \\
\hline & 6 & 1.047 & 1.554 & 1.119 & 2.666 & & 6 & 1.121 & 2.048 & 1.337 & 3.262 \\
\hline & 9 & 1.032 & 0.702 & 1.137 & 2.051 & & 9 & 1.114 & 1.184 & 1.331 & 2.630 \\
\hline & 12 & 1.011 & 0.411 & 1.091 & 2.004 & & 12 & 1.102 & 1.703 & 1.377 & 3.179 \\
\hline \multirow[t]{6}{*}{4} & 1 & 1.022 & 0.631 & 1.132 & 4.068 & 10 & 1 & 1.097 & 1.534 & 1.147 & 3.248 \\
\hline & 2 & 1.056 & 0.878 & 1.253 & 3.608 & & 2 & 1.060 & 0.812 & 1.280 & 3.076 \\
\hline & 4 & 1.065 & 1.079 & 1.314 & 3.460 & & 4 & 1.125 & 1.762 & 1.321 & 2.787 \\
\hline & 6 & 1.099 & 1.839 & 1.304 & 3.391 & & 6 & 1.126 & 2.075 & 1.384 & 3.098 \\
\hline & 9 & 1.126 & 1.340 & 1.419 & 3.242 & & 9 & 1.134 & 1.312 & 1.358 & 2.591 \\
\hline & 12 & 1.132 & 2.207 & 1.294 & 2.982 & & 12 & 1.147 & 2.330 & 1.482 & 3.476 \\
\hline
\end{tabular}

Note: RRMSPE denotes the ratio of the root mean squared prediction errors, which is the mean squared prediction error (RMSPE) from the benchmark model divided by the RMSPE from the competing Partial Least Squares factor model. DMW is the Diebold-Mariano-West statistics. We repeat estimations and forecasting starting from the first $50 \%$ observations until we (out-of-sample) forecast the last observation of the KFSTI. DMW statistics in bold denote the rejection of the null hypothesis of equal predictability at the $5 \%$ significance level in favor of our factor models. The critical values are from McCracken (2007) to avoid size distortion because the benchmark model is nested by our factor model.

Most RRMSPE values are strictly greater than 1, and the DMW test rejects the null of equal predictability favoring our factor models. That is, our PLS-RW model consistently outperforms the RW benchmark model in all forecast horizons and in both the recursive and the rolling window method. It should be noted that we use critical values from McCracken (2007) instead of the asymptotic critical values from the standard normal distribution, because the PLS-RW model nests the RW benchmark model.9)

9) Asymptotic critical values are not valid when one model nests the other model. 
Table 4: PLS-AR vs. AR: Foreign Exchange Market

\begin{tabular}{|c|c|c|c|c|c|c|c|c|c|c|c|}
\hline \multirow[b]{2}{*}{$k$} & \multirow[b]{2}{*}{$h$} & \multicolumn{2}{|c|}{ Recursive } & \multicolumn{2}{|c|}{ Rolling Window } & \multirow[b]{2}{*}{$k$} & \multirow[b]{2}{*}{$h$} & \multicolumn{2}{|c|}{ Recursive } & \multicolumn{2}{|c|}{ Rolling Window } \\
\hline & & RRMSPE & $D M W$ & RRMSPE & $D M W$ & & & RRMSPE & $D M W$ & RRMSPE & $D M W$ \\
\hline \multirow[t]{6}{*}{1} & 1 & 1.048 & 1.721 & 0.997 & -0.320 & 6 & 1 & 1.022 & 0.602 & 0.953 & -3.801 \\
\hline & 2 & 1.000 & 0.002 & 0.973 & -1.839 & & 2 & 0.989 & -0.371 & 0.944 & -2.565 \\
\hline & 4 & 1.001 & 0.262 & 0.995 & -1.035 & & 4 & 0.995 & -0.135 & 0.968 & -1.872 \\
\hline & 6 & 0.984 & -0.527 & 0.993 & -1.414 & & 6 & 0.896 & -2.981 & 0.984 & -1.023 \\
\hline & 9 & 0.951 & -2.547 & 0.998 & -0.657 & & 9 & 0.905 & -2.576 & 0.997 & -0.259 \\
\hline & 12 & 0.953 & -1.333 & 0.996 & -0.717 & & 12 & 0.979 & -0.502 & 0.969 & -1.354 \\
\hline \multirow[t]{6}{*}{2} & 1 & 1.054 & 1.658 & 0.985 & -0.970 & 8 & 1 & 1.029 & 0.710 & 0.954 & -3.566 \\
\hline & 2 & 0.999 & -0.044 & 0.955 & -2.196 & & 2 & 0.999 & -0.043 & 0.938 & -2.825 \\
\hline & 4 & 1.010 & 0.532 & 0.981 & -1.647 & & 4 & 1.031 & 0.900 & 0.972 & -1.517 \\
\hline & 6 & 0.983 & -0.428 & 0.991 & -0.992 & & 6 & 0.868 & -2.883 & 0.954 & -1.949 \\
\hline & 9 & 0.960 & -2.237 & 1.005 & 0.582 & & 9 & 0.907 & -2.643 & 0.981 & -0.910 \\
\hline & 12 & 0.963 & -1.396 & 0.993 & -0.457 & & 12 & 0.963 & -0.619 & 0.945 & -1.714 \\
\hline \multirow[t]{6}{*}{4} & 1 & 1.019 & 0.703 & 0.978 & -2.320 & 10 & 1 & 1.024 & 0.512 & 0.933 & -3.466 \\
\hline & 2 & 1.001 & 0.039 & 0.962 & -2.214 & & 2 & 0.987 & -0.315 & 0.923 & -2.945 \\
\hline & 4 & 1.001 & 0.048 & 0.960 & -3.191 & & 4 & 1.066 & 1.579 & 0.934 & -1.226 \\
\hline & 6 & 0.964 & -0.878 & 0.988 & -0.980 & & 6 & 0.877 & -2.568 & 0.897 & -2.589 \\
\hline & 9 & 0.921 & -2.291 & 1.025 & 0.976 & & 9 & 0.837 & -2.935 & 0.976 & -0.689 \\
\hline & 12 & 0.941 & -1.961 & 0.974 & -1.363 & & 12 & 0.993 & -0.160 & 0.926 & -2.081 \\
\hline
\end{tabular}

Note: RRMSPE denotes the ratio of the root mean squared prediction errors, which is the mean squared prediction error (RMSPE) from the benchmark model divided by the RMSPE from the competing Partial Least Squares factor model. DMW is the Diebold-Mariano-West statistics. We repeat estimations and forecasting starting from the first $50 \%$ observations until we (out-of-sample) forecast the last observation of the KFSTI. DMW statistics in bold denote the rejection of the null hypothesis of equal predictability at the $5 \%$ significance level in favor of our factor models. The critical values are from McCracken (2007) to avoid size distortion because the benchmark model is nested by our factor model.

Table 4 and Table 5 report the forecasting performance of the PLS-AR model (13) relative to the AR benchmark model (15). Results sharply contrast with earlier results reported in Table 2 and Table 3. The PLS-AR model outperforms the AR model only in the short-term forecast horizons. More specifically, the PLS-AR model outperforms the AR model in 1-month ahead out-of-sample forecast for the KFSTI-FX under the recursive forecasting scheme, while the AR model performs better in most other cases. The PLS-AR model performs relatively better for the KFSTI-Stock, as RRMSPE values are greater than 1 at least in one-month ahead forecast for the index under the both schemes. 
Table 5: PLS-AR vs. AR: Stock Market

\begin{tabular}{|c|c|c|c|c|c|c|c|c|c|c|c|}
\hline \multirow[b]{2}{*}{$k$} & \multirow[b]{2}{*}{$h$} & \multicolumn{2}{|c|}{ Recursive } & \multicolumn{2}{|c|}{ Rolling Window } & \multirow[b]{2}{*}{$k$} & \multirow[b]{2}{*}{$h$} & \multicolumn{2}{|c|}{ Recursive } & \multicolumn{2}{|c|}{ Rolling Window } \\
\hline & & RRMSPE & $D M W$ & RRMSPE & $D M W$ & & & RRMSPE & $D M W$ & RRMSPE & $D M W$ \\
\hline \multirow[t]{6}{*}{1} & 1 & 1.018 & 1.717 & 1.032 & 3.786 & 6 & 1 & 1.035 & 1.703 & 1.032 & 1.197 \\
\hline & 2 & 1.001 & 0.171 & 1.023 & 3.315 & & 2 & 1.011 & 0.699 & 1.030 & 1.162 \\
\hline & 4 & 0.991 & -1.763 & 1.037 & 3.116 & & 4 & 1.012 & 0.727 & 0.976 & -0.670 \\
\hline & 6 & 0.994 & -3.829 & 1.032 & 2.585 & & 6 & 0.991 & -0.777 & 0.945 & -1.276 \\
\hline & 9 & 0.992 & -3.448 & 1.011 & 1.357 & & 9 & 1.002 & 0.152 & 0.894 & -1.614 \\
\hline & 12 & 0.992 & -1.170 & 1.008 & 0.373 & & 12 & 0.989 & -0.511 & 0.910 & -1.359 \\
\hline \multirow[t]{6}{*}{2} & 1 & 1.021 & 1.789 & 1.035 & 2.765 & 8 & 1 & 1.053 & 2.049 & 1.013 & 0.477 \\
\hline & 2 & 1.001 & 0.139 & 1.019 & 1.644 & & 2 & 1.006 & 0.344 & 1.002 & 0.078 \\
\hline & 4 & 0.993 & -1.312 & 1.039 & 2.821 & & 4 & 1.016 & 0.991 & 0.925 & -1.793 \\
\hline & 6 & 0.990 & -3.169 & 1.019 & 0.871 & & 6 & 0.990 & -0.792 & 0.930 & -1.309 \\
\hline & 9 & 0.986 & -2.030 & 0.979 & -0.826 & & 9 & 1.004 & 0.263 & 0.838 & -2.262 \\
\hline & 12 & 0.992 & -0.470 & 0.942 & -1.311 & & 12 & 1.001 & 0.030 & 0.884 & -1.636 \\
\hline \multirow[t]{6}{*}{4} & 1 & 1.013 & 0.856 & 1.043 & 2.642 & 10 & 1 & 1.075 & 1.934 & 1.018 & 0.731 \\
\hline & 2 & 1.003 & 0.154 & 1.051 & 2.939 & & 2 & 0.997 & -0.128 & 0.996 & -0.127 \\
\hline & 4 & 0.995 & -0.500 & 1.052 & 2.503 & & 4 & 1.021 & 1.167 & 0.906 & -1.905 \\
\hline & 6 & 0.986 & -2.355 & 0.997 & -0.120 & & 6 & 0.983 & -1.189 & 0.886 & -2.004 \\
\hline & 9 & 0.989 & -0.764 & 0.983 & -0.375 & & 9 & 1.020 & 0.988 & 0.814 & -2.186 \\
\hline & 12 & 0.979 & -0.972 & 0.887 & -1.908 & & 12 & 1.009 & 0.339 & 0.862 & -1.972 \\
\hline
\end{tabular}

Note: RRMSPE denotes the ratio of the root mean squared prediction errors, which is the mean squared prediction error (RMSPE) from the benchmark model divided by the RMSPE from the competing Partial Least Squares factor model. DMW is the Diebold-Mariano-West statistics. We repeat estimations and forecasting starting from the first $50 \%$ observations until we (out-of-sample) forecast the last observation of the KFSTI. DMW statistics in bold denote the rejection of the null hypothesis of equal predictability at the $5 \%$ significance level in favor of our factor models. The critical values are from McCracken (2007) to avoid size distortion because the benchmark model is nested by our factor model.

Even though the performance of the PLS-AR model relative to the AR benchmark is not overwhelmingly good, it should be noted that the PLS-AR model can still provide useful early warning indicators of incoming danger to Korea's financial market. Financial crises often occur abruptly and unexpectedly. Given such tendency, it is good to have an instrument that generates warning signs before the systemic risks materialize in the financial market.

We repeat the same exercises using combinations of $\Delta \hat{c}_{t}$ and $\Delta \widehat{\mathrm{f}}_{t}$ and report the results in Table 6 through Table 9. That is, we extended the benchmark forecasting models using equal numbers of factors obtained from the PLS and the PC methods. 
For example, $k=4$ means that $\Delta \hat{c}_{1}, \Delta \hat{c}_{2}, \Delta \hat{f}_{1}$, and $\Delta \hat{f}_{2}$ are used as condensed predictor variables. Results are qualitatively similar to previous performances reported in Table 2 through Table 5. That is, marginal contributions of using PC factors $\left(\Delta \widehat{\mathrm{f}}_{t}\right)$ in addition to PLS factors $\left(\Delta \hat{c}_{t}\right)$ are mostly negligibly small.

\section{Table 6: PLS-PCA-RW vs. RW: Foreign Exchange Market}

\begin{tabular}{|c|c|c|c|c|c|c|c|c|c|c|c|}
\hline \multirow[b]{2}{*}{$k$} & \multirow[b]{2}{*}{$h$} & \multicolumn{2}{|c|}{ Recursive } & \multicolumn{2}{|c|}{ Rolling Window } & \multirow[b]{2}{*}{$k$} & \multirow[b]{2}{*}{$h$} & \multicolumn{2}{|c|}{ Recursive } & \multicolumn{2}{|c|}{ Rolling Window } \\
\hline & & RRMSPE & $D M W$ & RRMSPE & $D M W$ & & & RRMSPE & $D M W$ & RRMSPE & $D M W$ \\
\hline \multirow[t]{6}{*}{2} & 1 & 0.938 & -1.136 & 1.029 & 1.696 & 8 & 1 & 1.009 & 0.103 & 1.038 & 0.802 \\
\hline & 2 & 0.995 & -0.086 & 1.013 & 0.415 & & 2 & 1.076 & 0.750 & 1.080 & 1.688 \\
\hline & 4 & 1.057 & 0.846 & 1.045 & 1.466 & & 4 & 1.226 & 1.727 & 1.154 & 2.993 \\
\hline & 6 & 1.145 & 1.104 & 1.050 & 1.214 & & 6 & 1.327 & 2.222 & 1.180 & 3.005 \\
\hline & 9 & 1.171 & 2.460 & 1.027 & 0.655 & & 9 & 1.363 & 3.871 & 1.146 & 2.566 \\
\hline & 12 & 1.359 & 2.049 & 1.047 & 0.965 & & 12 & 1.493 & 1.999 & 1.135 & 2.056 \\
\hline \multirow[t]{6}{*}{4} & 1 & 0.962 & -0.518 & 1.037 & 1.417 & 10 & 1 & 0.954 & -0.508 & 1.064 & 2.185 \\
\hline & 2 & 1.016 & 0.216 & 1.029 & 0.709 & & 2 & 1.050 & 0.461 & 1.061 & 1.410 \\
\hline & 4 & 1.086 & 0.966 & 1.102 & 2.752 & & 4 & 1.217 & 1.937 & 1.129 & 2.640 \\
\hline & 6 & 1.222 & 1.609 & 1.154 & 2.995 & & 6 & 1.285 & 1.860 & 1.137 & 2.506 \\
\hline & 9 & 1.330 & 4.297 & 1.133 & 2.907 & & 9 & 1.340 & 3.518 & 1.167 & 2.959 \\
\hline & 12 & 1.536 & 2.336 & 1.095 & 1.643 & & 12 & 1.443 & 1.893 & 1.144 & 2.185 \\
\hline \multirow[t]{6}{*}{6} & 1 & 0.959 & -0.579 & 1.014 & 0.252 & 12 & 1 & 0.944 & -0.586 & 1.033 & 0.847 \\
\hline & 2 & 1.025 & 0.330 & 1.067 & 1.599 & & 2 & 1.045 & 0.411 & 1.028 & 0.419 \\
\hline & 4 & 1.101 & 1.005 & 1.124 & 3.425 & & 4 & 1.165 & 1.377 & 1.078 & 0.809 \\
\hline & 6 & 1.277 & 2.008 & 1.209 & 2.751 & & 6 & 1.163 & 0.910 & 1.092 & 1.485 \\
\hline & 9 & 1.324 & 3.590 & 1.132 & 2.450 & & 9 & 1.331 & 3.149 & 1.160 & 2.825 \\
\hline & 12 & 1.590 & 2.271 & 1.109 & 2.097 & & 12 & 1.576 & 2.037 & 1.131 & 2.755 \\
\hline
\end{tabular}

Note: RRMSPE denotes the ratio of the root mean squared prediction errors, which is the mean squared prediction error (RMSPE) from the benchmark model divided by the RMSPE from the competing Partial Least Squares factor model. DMW is the Diebold-Mariano-West statistics. We repeat estimations and forecasting starting from the first $50 \%$ observations until we (out-of-sample) forecast the last observation of the KFSTI. DMW statistics in bold denote the rejection of the null hypothesis of equal predictability at the $5 \%$ significance level in favor of our factor models. The critical values are from McCracken (2007) to avoid size distortion because the benchmark model is nested by our factor model. 
Table 7: PLS-PC-RW vs. RW: Stock Market

$$
\hat{y}_{t+j \mid t}^{P L S / P C_{R W}}=y_{t}+\hat{\varphi}_{j}^{\prime} \Delta z_{t} \text { vs. } \hat{y}_{t+j \mid t}^{B M_{R W}}=y_{t}
$$

\begin{tabular}{|c|c|c|c|c|c|c|c|c|c|c|c|}
\hline \multirow[b]{2}{*}{$k$} & \multirow[b]{2}{*}{$h$} & \multicolumn{2}{|c|}{ Recursive } & \multicolumn{2}{|c|}{ Rolling Window } & \multirow[b]{2}{*}{$k$} & \multirow[b]{2}{*}{$h$} & \multicolumn{2}{|c|}{ Recursive } & \multicolumn{2}{|c|}{ Rolling Window } \\
\hline & & RRMSPE & $D M W$ & RRMSPE & $D M W$ & & & RRMSPE & $D M W$ & RRMSPE & $D M W$ \\
\hline \multirow[t]{6}{*}{2} & 1 & 1.001 & 0.167 & 1.006 & 0.645 & 8 & 1 & 1.047 & 1.226 & 1.121 & 2.881 \\
\hline & 2 & 0.996 & -0.238 & 1.016 & 0.965 & & 2 & 1.079 & 1.228 & 1.243 & 3.171 \\
\hline & 4 & 0.993 & -0.402 & 1.018 & 1.001 & & 4 & 1.121 & 1.960 & 1.289 & 2.829 \\
\hline & 6 & 1.014 & 0.757 & 0.999 & -0.066 & & 6 & 1.102 & 2.064 & 1.289 & 2.964 \\
\hline & 9 & 1.016 & 0.488 & 0.984 & -0.545 & & 9 & 1.108 & 1.242 & 1.270 & 2.340 \\
\hline & 12 & 1.006 & 0.254 & 0.970 & -1.180 & & 12 & 1.103 & 2.005 & 1.304 & 2.956 \\
\hline \multirow[t]{6}{*}{4} & 1 & 1.042 & 1.001 & 1.067 & 3.071 & 10 & 1 & 1.053 & 1.306 & 1.147 & 2.863 \\
\hline & 2 & 1.050 & 0.882 & 1.149 & 3.312 & & 2 & 1.061 & 0.924 & 1.273 & 2.976 \\
\hline & 4 & 1.044 & 0.841 & 1.164 & 3.281 & & 4 & 1.116 & 1.754 & 1.296 & 2.878 \\
\hline & 6 & 1.092 & 1.852 & 1.178 & 3.173 & & 6 & 1.116 & 2.222 & 1.258 & 2.626 \\
\hline & 9 & 1.128 & 1.395 & 1.213 & 2.813 & & 9 & 1.127 & 1.399 & 1.248 & 2.139 \\
\hline & 12 & 1.105 & 2.099 & 1.162 & 2.576 & & 12 & 1.113 & 2.072 & 1.297 & 2.652 \\
\hline \multirow[t]{6}{*}{6} & 1 & 1.042 & 1.164 & 1.112 & 2.865 & 12 & 1 & 1.086 & 1.397 & 1.165 & 3.144 \\
\hline & 2 & 1.058 & 0.898 & 1.234 & 3.150 & & 2 & 1.058 & 0.769 & 1.277 & 2.916 \\
\hline & 4 & 1.061 & 1.055 & 1.263 & 2.745 & & 4 & 1.123 & 1.692 & 1.320 & 2.808 \\
\hline & 6 & 1.086 & 1.689 & 1.288 & 3.070 & & 6 & 1.131 & 1.966 & 1.359 & 3.040 \\
\hline & 9 & 1.120 & 1.233 & 1.285 & 2.411 & & 9 & 1.149 & 1.399 & 1.315 & 2.407 \\
\hline & 12 & 1.117 & 2.046 & 1.261 & 2.672 & & 12 & 1.137 & 2.123 & 1.399 & 3.064 \\
\hline
\end{tabular}

Note: RRMSPE denotes the ratio of the root mean squared prediction errors, which is the mean squared prediction error (RMSPE) from the benchmark model divided by the RMSPE from the competing Partial Least Squares factor model. DMW is the Diebold-Mariano-West statistics. We repeat estimations and forecasting starting from the first $50 \%$ observations until we (out-of-sample) forecast the last observation of the KFSTI. DMW statistics in bold denote the rejection of the null hypothesis of equal predictability at the $5 \%$ significance level in favor of our factor models. The asymptotic critical values from the standard normal distribution are used. 
Table 8: PLS-PCA-AR vs. AR: Foreign Exchange Market

$$
\hat{y}_{t+j \mid t}^{P L S / P C_{A R}}=\hat{\alpha}_{j} y_{t}+\hat{\omega}_{j}^{\prime} \Delta z_{t} \text { vs. } \hat{y}_{t+j \mid t}^{B M_{A R}}=\hat{\alpha}_{j} y_{t}
$$

\begin{tabular}{cccccccccccc} 
& \multicolumn{1}{c}{ Recursive } & \multicolumn{3}{c}{ Rolling Window } & \multicolumn{4}{c}{ Recursive } & \multicolumn{2}{c}{ Rolling Window } \\
$k$ & $h$ & RRMSPE & DMW & RRMISPE & DMW & $k$ & $h$ & RRMSPE & $D M W$ & RRMSPE & $D M W$ \\
\hline 2 & 1 & 1.033 & 1.244 & 0.997 & -0.268 & 8 & 1 & 1.030 & 0.752 & 0.939 & -3.054 \\
& 2 & 1.002 & 0.063 & 0.970 & -1.838 & 2 & 0.998 & -0.071 & 0.932 & -2.881 \\
& 4 & 0.999 & -0.134 & 0.996 & -0.784 & 4 & 1.020 & 0.434 & 0.949 & -1.320 \\
& 6 & 0.984 & -0.367 & 0.993 & -0.874 & 6 & 0.877 & -2.386 & 0.931 & -2.562 \\
& 9 & 0.947 & -2.168 & 1.020 & 0.711 & 9 & 0.899 & -2.191 & 0.967 & -1.092 \\
& 12 & 0.951 & -1.033 & 0.991 & -1.046 & 12 & 0.944 & -0.964 & 0.947 & -1.880 \\
\hline 4 & 1 & 1.033 & 0.977 & 0.973 & -2.458 & 10 & 1 & 1.005 & 0.098 & 0.937 & -3.363 \\
& 2 & 0.997 & -0.117 & 0.962 & -2.206 & 2 & 0.998 & -0.056 & 0.915 & -3.006 \\
& 4 & 0.988 & -0.352 & 0.988 & -1.091 & 4 & 0.978 & -0.558 & 0.925 & -2.026 \\
& 6 & 0.954 & -1.054 & 0.990 & -0.882 & 6 & 0.853 & -1.860 & 0.934 & -2.107 \\
& 9 & 0.926 & -1.991 & 1.026 & 1.369 & 9 & 0.877 & -1.757 & 0.952 & -1.384 \\
& 12 & 0.980 & -0.516 & 0.983 & -1.049 & 12 & 1.007 & 0.063 & 0.903 & -2.821 \\
\hline 6 & 1 & 1.027 & 0.712 & 0.966 & -2.322 & 12 & 1 & 0.983 & -0.299 & 0.928 & -3.176 \\
2 & 0.998 & -0.061 & 0.944 & -2.557 & 2 & 0.964 & -0.806 & 0.894 & -2.714 \\
4 & 1.012 & 0.329 & 0.971 & -1.856 & 4 & 0.970 & -0.434 & 0.885 & -1.253 \\
6 & 0.922 & -2.153 & 0.991 & -0.549 & 6 & 0.806 & -1.785 & 0.905 & -2.078 \\
9 & 0.913 & -1.836 & 0.988 & -0.659 & 9 & 0.865 & -2.357 & 0.963 & -1.101 \\
12 & 0.963 & -1.138 & 0.965 & -1.314 & 12 & 0.988 & -0.111 & 0.894 & -2.771 \\
\hline
\end{tabular}

Note: RRMSPE denotes the ratio of the root mean squared prediction errors, which is the mean squared prediction error (RMSPE) from the benchmark model divided by the RMSPE from the competing Partial Least Squares factor model. DMW is the Diebold-Mariano-West statistics. We repeat estimations and forecasting starting from the first $50 \%$ observations until we (out-of-sample) forecast the last observation of the KFSTI. DMW statistics in bold denote the rejection of the null hypothesis of equal predictability at the $5 \%$ significance level in favor of our factor models. The critical values are from McCracken (2007) to avoid size distortion because the benchmark model is nested by our factor model. 
Table 9: PLS-PCA-AR vs. AR: Stock Market

$$
\hat{y}_{t+j \mid t}^{P L S / P C_{A R}}=\hat{\alpha}_{j} y_{t}+\hat{\omega}_{j}^{\prime} \Delta z_{t} \text { vs. } \hat{y}_{t+j \mid t}^{B M_{A R}}=\hat{\alpha}_{j} y_{t}
$$

\begin{tabular}{|c|c|c|c|c|c|c|c|c|c|c|c|}
\hline \multirow[b]{2}{*}{$k$} & \multirow[b]{2}{*}{$h$} & \multicolumn{2}{|c|}{ Recursive } & \multicolumn{2}{|c|}{ Rolling Window } & \multirow[b]{2}{*}{$k$} & \multirow[b]{2}{*}{$h$} & \multicolumn{2}{|c|}{ Recursive } & \multicolumn{2}{|c|}{ Rolling Window } \\
\hline & & RRMSPE & $D M W$ & RRMSPE & $D M W$ & & & RRMSPE & $D M W$ & RRMSPE & $D M W$ \\
\hline \multirow[t]{6}{*}{2} & 1 & 1.021 & 1.510 & 1.039 & 2.691 & 8 & 1 & 1.044 & 1.733 & 1.020 & 0.768 \\
\hline & 2 & 1.001 & 0.135 & 1.022 & 1.897 & & 2 & 1.011 & 0.609 & 1.002 & 0.100 \\
\hline & 4 & 0.990 & -1.818 & 1.038 & 2.722 & & 4 & 1.021 & 1.265 & 0.928 & -1.829 \\
\hline & 6 & 0.993 & -2.431 & 1.018 & 0.954 & & 6 & 0.984 & -1.202 & 0.922 & -1.516 \\
\hline & 9 & 0.997 & -0.349 & 0.973 & -0.886 & & 9 & 1.019 & 0.942 & 0.820 & -2.984 \\
\hline & 12 & 0.999 & -0.091 & 0.923 & -1.604 & & 12 & 1.018 & 0.633 & 0.874 & -2.109 \\
\hline \multirow[t]{6}{*}{4} & 1 & 1.033 & 1.344 & 1.028 & 1.901 & 10 & 1 & 1.053 & 1.936 & 1.026 & 0.890 \\
\hline & 2 & 1.015 & 0.782 & 1.027 & 2.017 & & 2 & 1.004 & 0.234 & 0.998 & -0.049 \\
\hline & 4 & 0.999 & -0.108 & 1.015 & 0.902 & & 4 & 1.021 & 1.307 & 0.917 & -1.880 \\
\hline & 6 & 1.002 & 0.242 & 1.002 & 0.090 & & 6 & 0.990 & -0.634 & 0.887 & -1.763 \\
\hline & 9 & 1.011 & 0.649 & 0.957 & -1.076 & & 9 & 1.022 & 1.009 & 0.805 & -2.280 \\
\hline & 12 & 0.991 & -0.471 & 0.916 & -1.696 & & 12 & 1.027 & 0.914 & 0.848 & -1.750 \\
\hline \multirow[t]{6}{*}{6} & 1 & 1.050 & 2.068 & 1.016 & 0.702 & 12 & 1 & 1.069 & 1.729 & 1.034 & 1.189 \\
\hline & 2 & 1.010 & 0.485 & 1.019 & 0.775 & & 2 & 0.999 & -0.062 & 0.993 & -0.183 \\
\hline & 4 & 1.001 & 0.056 & 0.953 & -1.359 & & 4 & 1.020 & 1.069 & 0.906 & -1.853 \\
\hline & 6 & 0.993 & -0.784 & 0.918 & -2.330 & & 6 & 0.999 & -0.081 & 0.887 & -1.884 \\
\hline & 9 & 1.015 & 1.191 & 0.846 & -2.666 & & 9 & 1.047 & 1.846 & 0.809 & -2.298 \\
\hline & 12 & 0.996 & -0.191 & 0.869 & -2.200 & & 12 & 1.024 & 0.832 & 0.848 & -1.903 \\
\hline
\end{tabular}

Note: RRMSPE denotes the ratio of the root mean squared prediction errors, which is the mean squared prediction error (RMSPE) from the benchmark model divided by the RMSPE from the competing Partial Least Squares factor model. DMW is the Diebold-Mariano-West statistics. We repeat estimations and forecasting starting from the first $50 \%$ observations until we (out-of-sample) forecast the last observation of the KFSTI. DMW statistics in bold denote the rejection of the null hypothesis of equal predictability at the $5 \%$ significance level in favor of our factor models. The critical values are from McCracken (2007) to avoid size distortion because the benchmark model is nested by our factor model. 


\subsection{Comparisons with the PC Models}

This sub-section compares the out-of-sample prediction performances of the PLS models relative to those of the PC models using the RRMSPE criteria, the RMSPE from the PLS model divided by the RMSPE from the corresponding PC model. That is, RRMSPE greater than 1 implies a better performance of the PLS model.

As can be seen in Figure 6 for the KFSTI-FX, the PLS-RW model outperforms the PC-RW model in all forecast horizons we consider. It is interesting to see that the PLS-RW model's relative performance becomes better as we employ more factor estimates or when forecast horizons become longer. On the other hand, we observed qualitatively similar performance of the PLS-AR model and the PC-AR model in predicting the KFSTI-FX, even though the PLS-AR model tend to perform better in short-term forecast horizons with many factor estimates.

The PLS-RW model again demonstrates substantially better performance than the PC-RW model in predicting the KFSTI-Stock in all forecast horizons under both the recursive and the fixed-size rolling window schemes. Interestingly, the PC-AR model overall outperforms the PLS-AR model for the KFSTI-Stock under the recursive scheme, while the latter outperforms the former under the fixed-size rolling window scheme. This seems to explain slight improvements in forecasting performance, see Table 5 and Table 9, under the recursive scheme when we combine PLS and PC factors together.

Lastly, we compare the performances of the PLS-AR model and the PLS-RW model using the RRMSPE criteria. RRMSPE greater than 1 implies that the PLS- AR model outperforms the PLS-RW model. Results are reported in Figure 8. It should be noted that both PLS models perform similarly well in short-term forecast horizons unless very small numbers of factors are employed. However, as the forecast horizon increases, the PLS-AR model tend to outperform the PLS-RW model. Note that the PLS-RW is based on the RW model, which is a "no change" prediction model. If the KFSTI obeys a mean reverting stochastic process, RW type models would not perform well in long-term forecast horizons. To check this possibility, we employed the conventional ADF test, which rejected the null of nonstationarity at the $5 \%$ significance level for both indices, confirming the conjecture described earlier.10) 
Figure 6: Cross-Comparisons: Foreign Exchange Market
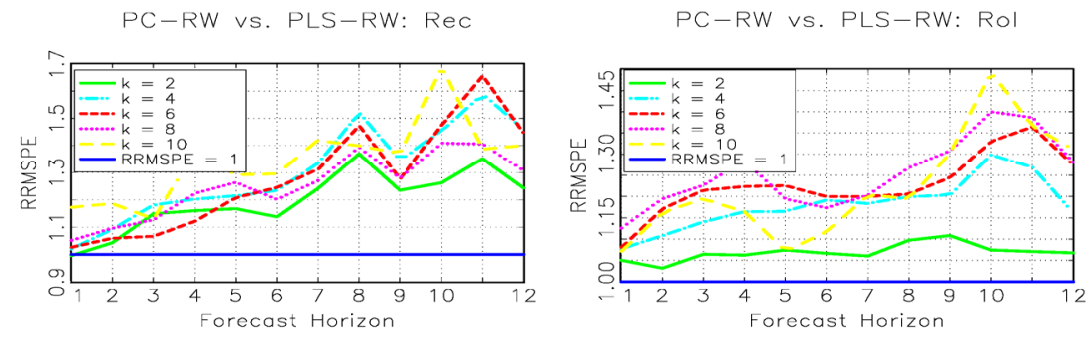

PC-AR VS. PLS-AR: ReC

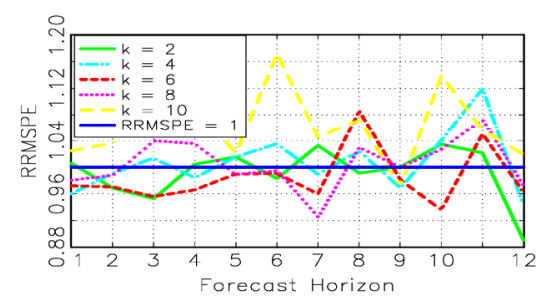

PC-AR VS. PLS-AR: ROI

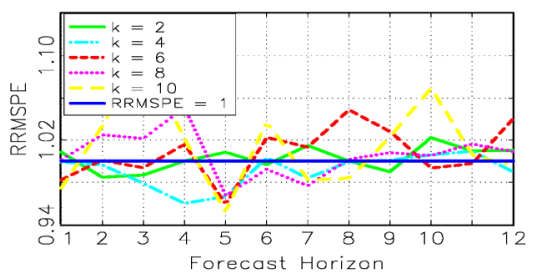

Note: We report the RRMSPE defined as the RMSPE of the PC method divided the RMSPE of the PLS. That is, the PLS method outperforms the PC method when RRMSPE is greater than one.

Figure 7: Cross-Comparisons: Stock Market
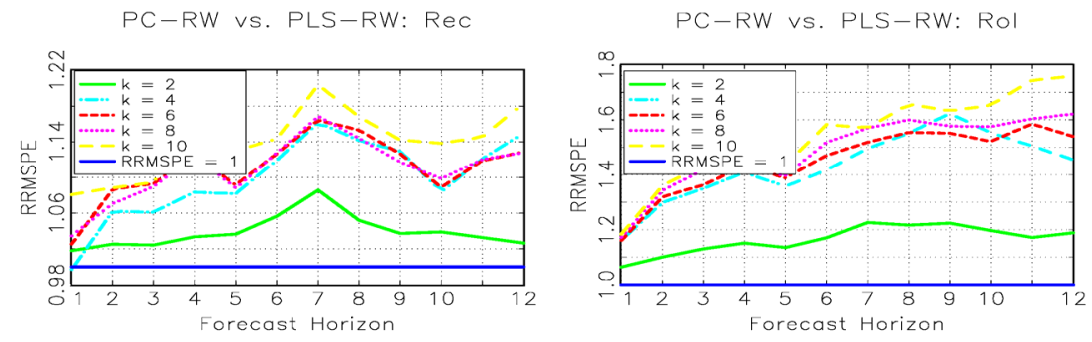

PC-AR vS. PLS-AR: Rec
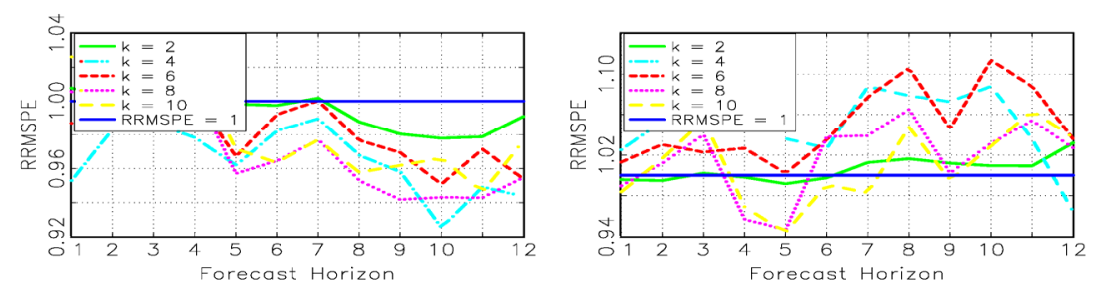

Note: We report the RRMSPE defined as the RMSPE of the PC method divided the RMSPE of the PLS. That is, the PLS method outperforms the PC method when RRMSPE is greater than one.

10) Results are available upon requests. 
Figure 8: Cross-Comparisons: PLS-RW vs. PLS-AR

KFSTI-FX: Rec

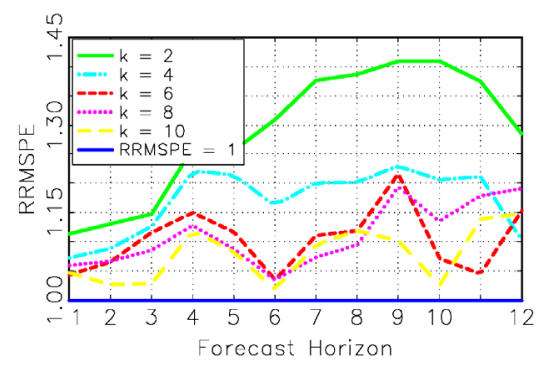

KFSTI-Stock: Rec

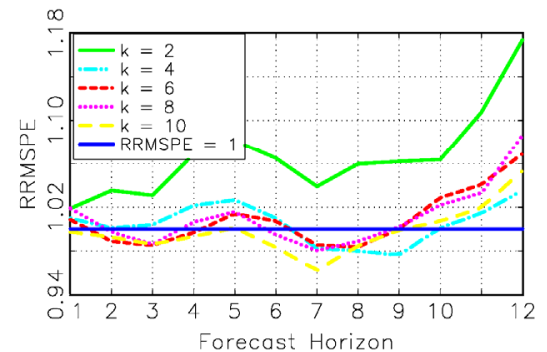

KFSTI-FX: Ro

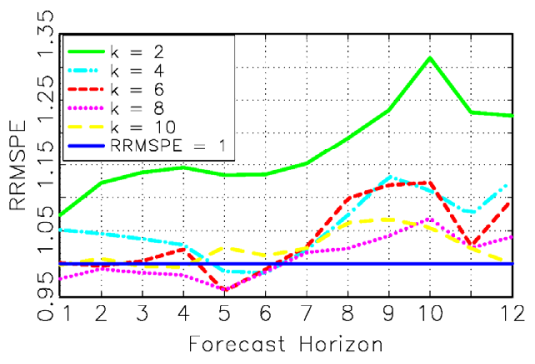

KFSTI-Stock: Rol

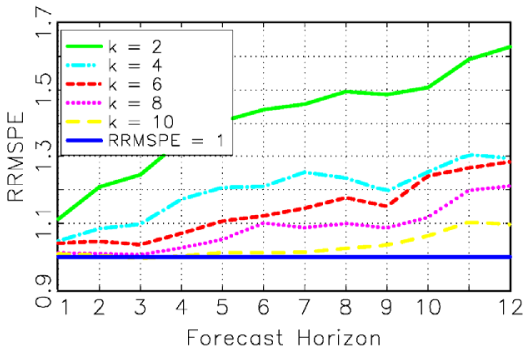

Note: We report the RRMSPE defined as the RMSPE of the PLS-RW model divided the RMSPE of the PLS-AR model. That is, the PLS-AR model outperforms the PLS-RW model when RRMSPE is greater than one.

\section{Concluding Remarks}

This paper proposes a factor-augmented forecasting model for the systemic risks in Korea's financial markets using the partial least squares (PLS) method as an alternative to the method of the principal components (PC). Unlike PC factor models that estimate common factors solely from predictor variables, the PLS approach generates the target specific common factors utilizing covariances between the predictors and the target variable.

Taking the Bank of Korea's Financial Stress Index (KFSTI) as a proxy variable of the financial vulnerability in Korea, we applied PLS to a large panel of 198 monthly frequency macroeconomic variables and the KFSTI from October 2000 to June 2016. Obtaining PLS common factors, we augmented the 
two benchmark models, the random walk (RW) model and the stationary autoregressive (AR) type model, with estimated PLS factors to out-of-sample forecast the KFSTI for the foreign exchange market and the stock market. We then implemented an array of out-of-sample prediction exercises using the recursive (expanding window) and the fixed-size rolling window schemes for 1-month to 1-year forecast horizons.

We evaluate our proposed PLS factor-augmented forecasting models via the ratio of the root mean squared prediction error and the Diebold-Mariano-West statistics. Our PLS-RW models consistently outperform the nonstationary random walk benchmark model. On the other hand, the PLS-AR forecasting models perform better than the AR models only for short-term forecast horizons. That is, unlike the PLS-RW model, the performance of the PLS-AR model is not overwhelmingly better than its benchmark. However, it should be noted that the PLS-AR model, and of course the PLS-RW model, can still provide potentially useful early warning signs of financial distress before the systemic risks materialize in Korea's financial market within a month. Combining all together, the PLS factor models perform much better than the PC factor models especially when the models are combined with the nonstationary random walk benchmark model. 


\section{References}

Andersson, M. (2009), "A Comparison of Nine PLS1 Algorithms," Journal of Chemometrics, Vol. 23, pp. 518-529.

Bai, J., and S. Ng (2004), "A PANIC Attack on Unit Roots and Cointegration," Econometrica, Vol. 72(4), pp. 1127-1177.

Boivin, J., and S. Ng (2006), "Are more data always better for factor analysis?," Journal of Econometrics, Vol. 132(1), pp. 169-194.

Christensen, I., and F. Li (2014), "Predicting Financial Stress Events: A Signal Extraction Approach," Bank of Canada Working Paper No. 2014-37.

Cipollini, A., and G. Kapetanios (2009), "Forecasting Financial Crises and Contagion in Asia using Dynamic Factor Analysis," Journal of Empirical Finance, Vol. 16(2), pp. 188-200.

Edison, H. J. (2003), "Do Indicators of Financial Crises Work? An Evaluation of an Early Warning System.," International Journal of Finance and Economics, Vol. 8(1), pp. 11-53.

EI-Shagi, M., T. Knedlik, and G. von Schweinitz (2013), "Predicting Financial Crises: The (Statistical) Significance of the Signals Approach," Journal of International Money and Finance, Vol. 35, pp. 75-103.

Eichengreen, B., A. K. Rose, and C. Wyplosz (1995), "Exchange Market Mayhem: The Antecedents and Aftermath of Speculative Attacks," Economic Policy, Vol. 10(21), pp. 249-312.

Frankel, J., and G. Saravelos (2012), "Can Leading Indicators Assess Country Vulnerability? Evidence from the 2008-09 Global Financial Crisis," Journal of International Economics, Vol. 87, pp. 216-231.

Frankel, J. A., and A. K. Rose (1996), "Currency Crashes in Emerging Markets: An Empirical Treatment," Journal of International Economics, Vol. 41(3/4), pp. 351-366. 
Girton, and Roper (1977), "A Monetary Model of Exchange Market Pressure Applied to the Postwar Canadian Experience," American Economic Review, Vol. 67, pp. 537-548.

Groen, J., and G. Kapetanios (2016), "Revisiting Useful Approaches to Datarich Macroeconomic Forecasting," Computational Statistics and Data Analysis, Vol. 100, pp. 221-239.

Helland, I. S. (1990), "Partial Least Squares Regression and Statistical Models," Scandinavian Journal of Statistics, Vol. 17, pp. 97-114.

Kaminsky, G., S. Lizondo, and C. Reinhart (1998), "Leading Indicators of Currency Crises," IMF Working Paper No. 45.

Kelly, B., and S. Pruitt (2015), "The Three-pass Regression Filter: A New Approach to Forecasting using Many Predictors," Journal of Econometrics, Vol. 186(2), pp. 294-316.

Kim, H., W. Shi, and H. H. Kim (2016), "Forecasting Financial Stress Indices in Korea: A Factor Model Approach,” Auburn Economics Working Paper Series 2016-10.

McCracken, M. W. (2007), "Asymptotics for Out of Sample Tests of Granger Causality," Journal of Econometrics, Vol. 140, pp. 719-752.

Nelson, C. R., and C. I. Plosser (1982), "Trends and Random Walks in Macroeconmic Time Series: Some Evidence and Implications," Journal of Monetary Economics, Vol. 10(2), pp. 139-162.

Oet, M. V., R. Eiben, T. Bianco, D. Gramlich, and S. J. Ong (2011), "The Financial Stress Index: Identification of System Risk Conditions," Federal Reserve Bank of Cleveland Working Paper No. 1130.

Reinhart, C. M., and K. S. Rogoff (2009), This Time Is Different: Eight Centuries of Financial Folly, vol. 1 of Economics Books, Princeton University Press. 
(2014), "Recovery from Financial Crises: Evidence from 100 Episodes," American Economic Review Papers and Proceedings, Vol. 104(5), pp. 50-55.

Sachs, J., A. Tornell, and A. Velasco (1996), "Financial Crises in Emerging Markets: The Lessons from 1995," Brookings Papers on Economic Activity, Vol. 27(1), pp. 147-199.

Stock, J. H., and M. W. Watson (2002), "Macroeconomic Forecasting using Diffusion Indexes," Journal of Business and Economic Statistics, Vol. 20(2), pp. 147-162.

Wold, H. (1982), Soft modelling: the basic design and some extensions, vol. 1 of Systems under indirect observation Part II, North-Holland, Amsterdam. 


\section{부분최소자승법 모형을 통한 금융스트레스 지수 예측력 제고}

김형우*, 고경환**

금융위기를 사전에 예측하기 위해 다수의 중앙은행은 금융시장 스트레스 지 수를 작성하여 활용하고 있으며, 한국은행도 2007년부터 동 지수를 작성하여 발 표하고 있다. 본고에서는 이러한 금융스트레스 지수에 대한 예측력을 제고하기 위한 방법을 제시하고, 기존 예측 모형들과 비교·분석하였다. 기존 연구들은 주로 주성분분석을 통해 여러 데이터에서 공통요인을 추출하여 예측에 활용하는 것이 일반적이었으나, 본 연구에서는 예측하고자 하는 변수와 거시데이터 간 관계를 고려하는 방법인 부분최소자승법을 도입하였다. 198 개의 거시·금융 데이터에서 부분최소자승법을 활용하여 잠재된 공통요인을 추출하였으며, 이 공통요인을 랜 덤워크 모형과 자기회귀 모형 등에 추가하여 지수를 예측하였다. 한편, 벤치마크 모형으로 랜덤워크 모형과 자기회귀 모형을 설정하고, 주성분분석으로 추출한 공 통요인을 추가하여 부분최소자승법을 활용한 모형과 비교하였다. 각 모형들의 예 측력 비교에는 예측오차 평균제곱근비율(RRMSPE) 및 Diebold-Mariano-West 통계량을 활용하였다. 분석결과 부분최소자승법을 통해 추출한 공통요인을 활용 한 모형 중 랜덤워크 모형은 모든 예측 기간에서, 자기회귀 모형은 단기 예측에서 벤치마크 모형에 비해 예측력이 우월한 것으로 나타났다.

핵심 주제어: 부분최소자승법, 주성분분석, 금융스트레스지수, 표본외 예측, RRMSPE, Diebold-Mariano-West 검정

JEL Classification: C38, C53, C55, E44, E47, G01, G17

* Auburn University 경제학과 교수 (전화: +1-334-844-2928, E-mail: gmmkim@gmail.com) ** 한국은행 제주본부 경제조사팀 과장 (전화: 064-720-2513, E-mail: kyunghwan.ko@bok.or.kr)

본 연구내용은 집필자의 개인의견이며 한국은행의 공식견해와는 무관합니다. 따라서 본 논문의 내용을 보도하거나 인용할 경우에는 집필자 명을 반드시 명시하여 주시기 바랍니다. 


\section{$\mathrm{BOK}$ 경제연구 발간목록}

한국은행 경제연구원에서는 Working Paper인 ${ }^{\circledR} \mathrm{BOK}$ 경제연구』를 수시로 발간하고 있습니다. ${ }^{『} \mathrm{BOK}$ 경제연구』는 주요 경제 현상 및 정책 효과에 대한 직관적 설명 뿐 아니라 깊이 있는 이론 또는 실증 분석을 제공함으로써 엄밀한 논증에 초점을 두는 학술논문 형태의 연구이며 한국은행 직원 및 한국은행 연구용역사업의 연구 결과물이 수록되고 있습니다.

${ }^{『} \mathrm{BOK}$ 경제연구』 는 한국은행 경제연구원 홈페이지(http://imer.bok.or.kr)에서 다운로드하여 보실 수 있습니다.

제2014-1 Network Indicators for Monitoring

Intraday Liquidity in BOK-Wire+

2 중소기업에 대한 신용정책 효과

3 경제충격 효과의 산업간 공행성 분석

4 서비스업 발전을 통한 내외수 균형성장 기대효과 및 리스크

5 Cross-country-heterogeneous and Time-varying Effects of Unconventional Monetary Policies in AEs on Portfolio Inflows to EMEs

6 인터넷뱅킹, 결제성예금 및 은행 수익성과의 관계 분석

7 Dissecting Foreign Bank Lending Behavior During the 2008-2009 Crisis

8 The Impact of Foreign Banks on Monetary Policy Transmission during the Global Financial Crisis of 2008-2009: Evidence from Korea

9 Welfare Cost of Business Cycles in Economies with Individual Consumption Risk

10 Investor Trading Behavior Around the Time of Geopolitical Risk Events: Evidence from South Korea

11 Imported-Inputs Channel of Exchange Rate Pass-Through: Evidence from Korean Firm-Level Pricing Survey
Seungjin Baek ·

Kimmo Soram ki . Jaeho Yoon

정호성·임호성

황선웅·민성환 ·

신동현·김기호

김승원 · 황광명

Kyoungsoo Yoon •

Christophe Hurlin

이동규·전봉걸

Moon Jung Choi •

Eva Gutierrez •

Maria Soledad Martinez Peria

Bang Nam Jeon

Hosung Lim $\cdot \mathrm{Ji} \mathrm{Wu}$

Martin Ellison •

Thomas J. Sargent

Young Han Kim •

Hosung Jung

Jae Bin Ahn .

Chang-Gui Park 


\begin{tabular}{|c|c|c|}
\hline 제2014 -12 & 비대칭 금리기간구조에 대한 실증분석 & 김기호 \\
\hline 13 & $\begin{array}{l}\text { The Effects of Globalization } \\
\text { on Macroeconomic Dynamics } \\
\text { in a Trade-Dependent Economy: } \\
\text { the Case of Korea }\end{array}$ & Fabio Milani · Sung Ho Park \\
\hline 14 & $\begin{array}{l}\text { 국제 포트폴리오투자 행태 분석: 채권-주식 } \\
\text { 투자자금간 상호관계를 중심으로 }\end{array}$ & 이주용 · 김근영 \\
\hline 15 & $\begin{array}{l}\text { 북한 경제의 추격 성장 가능성과 } \\
\text { 정책 선택 시나리오 }\end{array}$ & 이근 · 최지영 \\
\hline 16 & $\begin{array}{l}\text { Mapping Korea's International Linkages } \\
\text { using Generalised Connectedness Measures }\end{array}$ & Hail Park $\cdot$ Yongcheol Shin \\
\hline 17 & $\begin{array}{l}\text { 국제자본이동 하에서 환율신축성과 } \\
\text { 경상수지 조정: 국가패널 분석 }\end{array}$ & 김근영 \\
\hline 18 & $\begin{array}{l}\text { 외국인 투자자가 외환시장과 주식시장 간 } \\
\text { 유동성 동행화에 미치는 영향 }\end{array}$ & 김준한 $\cdot$ 이지은 \\
\hline 19 & $\begin{array}{l}\text { Forecasting the Term Structure } \\
\text { of Government Bond Yields } \\
\text { Using Credit Spreads and Structural Breaks }\end{array}$ & $\begin{array}{l}\text { Azamat Abdymomunov } \\
\text { Kyu Ho Kang } \\
\text { Ki Jeong Kim }\end{array}$ \\
\hline 20 & $\begin{array}{l}\text { Impact of Demographic Change } \\
\text { upon the Sustainability of Fiscal Policy }\end{array}$ & $\begin{array}{l}\text { Younggak Kim· } \\
\text { Myoung Chul Kim } \\
\text { Seongyong Im }\end{array}$ \\
\hline 21 & $\begin{array}{l}\text { The Impact of Population Aging } \\
\text { on the Countercyclical Fiscal Stance in Korea, } \\
\text { with a Focus on the Automatic Stabilizer }\end{array}$ & $\begin{array}{l}\text { Tae-Jeong Kim } \cdot \\
\text { Mihye Lee } \cdot \text { Robert Dekle }\end{array}$ \\
\hline 22 & $\begin{array}{l}\text { 미 연준과 유럽중앙은행의 비전통적 통화정책 } \\
\text { 수행원칙에 관한 고찰 }\end{array}$ & 김병기·김진일 \\
\hline 23 & $\begin{array}{l}\text { 우리나라 일반인의 인플레이션 기대 형성 } \\
\text { 행태 분석 }\end{array}$ & 이한규·최진호 \\
\hline
\end{tabular}




\section{제2014-24 Nonlinearity in Nexus between Working Hours and Productivity \\ Strategies for Reforming Korea's Labor Market to Foster Growth}

26
글로벌 금융위기 이후 성장잠재력 확충: 2014 한국은행 국제컨퍼런스 결과보고서

인구구조 변화가 경제성장률에 미치는 영향: 자본이동의 역할에 대한 논의를 중심으로

\section{Safe Assets}

확장된 실업지표를 이용한

우리나라 노동시장에서의 이력현상 분석

Entropy of Global Financial Linkages

International Currencies Past, Present and Future: Two Views from Economic History

금융체제 이행 및 통합 사례:

남북한 금융통합에 대한 시사점

Measuring Price-Level Uncertainty and Instability in the U.S., 1850-2012

고용보호제도가 노동시장 이원화 및 노동생산성에 미치는 영향

해외충격시 외화예금의 역할 : 주요 신흥국 신용스프레드에 미치는 영향을 중심으로

실업률을 고려한 최적 통화정책 분석

우리나라 무역거래의 결제통화 결정요인 분석

Global Liquidity Transmission to Emerging Market Economies, and Their Policy Responses
Dongyeol Lee •

Hyunjoon Lim

Mai Dao · Davide Furceri • Jisoo Hwang . Meeyeon Kim -

Tae-Jeong Kim

한국은행 경제연구원

손종칠

Robert J. Barro

김현학 · 황광명

Daeyup Lee

Barry Eichengreen

김병연

Timothy Cogley •

Thomas J. Sargent

김승원

정호성 - 우준명

김인수 · 이명수

황광명 · 김경민 ·

노충식 - 김미진

Woon Gyu Choi •

Taesu Kang ·

Geun-Young Kim •

Byongju Lee 
제2015-1 글로벌 금융위기 이후 주요국

통화정책 운영체계의 변화

2 미국 장기시장금리 변동이 우리나라 금리기간구조에 미치는 영향 분석 및 정책적 시사점

3 직간접 무역연계성을 통한 해외충격의 우리나라 수출입 파급효과 분석

4 통화정책 효과의 지역적 차이

5 수입중간재의 비용효과를 고려한 환율변동과 수출가격 간의 관계

6 중앙은행의 정책금리 발표가 주식시장 유동성에 미치는 영향

7 은행 건전성지표의 변동요인과 거시건전성 규제의 영향

8 Price Discovery and Foreign Participation in The Republic of Korea's Government Bond Futures and Cash Markets

9 규제가 노동생산성에 미치는 영향: 한국의 산업패널 자료를 이용한 실증분석

10 인구 고령화와 정년연장 연구 (세대 간 중첩모형(OLG)을 이용한 정량 분석)

11 예측조합 및 밀도함수에 의한 소비자물가 상승률 전망

12

Failure Risk and the Cross-Section of Hedge Fund Returns

14 Global Liquidity and Commodity Prices
김병기·김인수

강규호·오형석

최문정·김근영

김기호

김경민

이지은

강종구

Jaehun Choi - Hosung Lim •

Rogelio Jr. Mercado •

Cyn-Young Park

이동렬·최종일·이종한

홍재화·강태수

김현학

우준명

Jung-Min Kim

Hyunju Kang •

Bok-Keun $\mathrm{Yu}$. Jongmin $\mathrm{Yu}$

Jieun Lee $\cdot$ Kee H. Chung and Stock Market Liquidity 


\begin{tabular}{|c|c|c|}
\hline 제2015-16 & $\begin{array}{l}\text { 바젤피 은행 경기대응완충자본 규제의 } \\
\text { 기준지표에 대한 연구 }\end{array}$ & 서현덕·이정연 \\
\hline 17 & 우리나라 대출 수요와 공급의 변동요인 분석 & 강종구·임호성 \\
\hline 18 & 북한 인구구조의 변화 추이와 시사점 & 최지영 \\
\hline 19 & $\begin{array}{l}\text { Entry of Non-financial Firms and Competition } \\
\text { in the Retail Payments Market }\end{array}$ & Jooyong Jun \\
\hline 20 & $\begin{array}{l}\text { Monetary Policy Regime Change } \\
\text { and Regional Inflation Dynamics: } \\
\text { Looking through the Lens of } \\
\text { Sector-Level Data for Korea }\end{array}$ & $\begin{array}{l}\text { Chi-Young Choi } \\
\text { Joo Yong Lee } \\
\text { Roisin O'Sullivan }\end{array}$ \\
\hline 21 & $\begin{array}{l}\text { Costs of Foreign Capital Flows } \\
\text { in Emerging Market Economies: } \\
\text { Unexpected Economic Growth } \\
\text { and Increased Financial Market Volatility }\end{array}$ & $\begin{array}{l}\text { Kyoungsoo Yoon. } \\
\text { Jayoung Kim }\end{array}$ \\
\hline 22 & $\begin{array}{l}\text { 글로벌 금리 정상화와 통화정책 과제: } \\
\text { 2015년 한국은행 국제컨퍼런스 결과보고서 }\end{array}$ & 한국은행 경제연구원 \\
\hline 23 & $\begin{array}{l}\text { The Effects of Global Liquidity } \\
\text { on Global Imbalances }\end{array}$ & $\begin{array}{l}\text { Marie-Louise DJIGBENOU-KRE · } \\
\text { Hail Park }\end{array}$ \\
\hline 24 & 실물경기를 고려한 내재 유동성 측정 & 우준명·이지은 \\
\hline 25 & Deflation and Monetary Policy & Barry Eichengreen \\
\hline 26 & $\begin{array}{l}\text { Macroeconomic Shocks } \\
\text { and Dynamics of Labor Markets in Korea }\end{array}$ & $\begin{array}{l}\text { Tae Bong Kim } \cdot \\
\text { Hangyu Lee }\end{array}$ \\
\hline 27 & $\begin{array}{l}\text { Reference Rates and Monetary Policy } \\
\text { Effectiveness in Korea }\end{array}$ & $\begin{array}{l}\text { Heung Soon Jung } \\
\text { Dong Jin Lee } \\
\text { Tae Hyo Gwon } \\
\text { Se Jin Yun }\end{array}$ \\
\hline 28 & Energy Efficiency and Firm Growth & $\begin{array}{l}\text { Bongseok Choi } \\
\text { Wooyoung Park } \\
\text { Bok-Keun Yu }\end{array}$ \\
\hline 29 & $\begin{array}{l}\text { An Analysis of Trade Patterns } \\
\text { in East Asia and the Effects of } \\
\text { the Real Exchange Rate Movements }\end{array}$ & $\begin{array}{l}\text { Moon Jung Choi } \\
\text { Geun-Young Kim• } \\
\text { Joo Yong Lee }\end{array}$ \\
\hline 30 & $\begin{array}{l}\text { Forecasting Financial Stress Indices in } \\
\text { Korea: A Factor Model Approach }\end{array}$ & $\begin{array}{l}\text { Hyeongwoo Kim } \\
\text { Hyun Hak Kim. } \\
\text { Wen Shi }\end{array}$ \\
\hline
\end{tabular}


제2016 -1 The Spillover Effects of U.S. Monetary Policy on Emerging Market Economies: Breaks, Asymmetries and Fundamentals

2 Pass-Through of Imported Input Prices to Domestic Producer Prices:

Evidence from Sector-Level Data

3 Spillovers from U.S. Unconventional Monetary Policy and Its Normalization to Emerging Markets: A Capital Flow Perspective

4 Stock Returns and Mutual Fund Flows in the Korean Financial Market:

A System Approach

5 정책금리 변동이 성별·세대별 고용률에 미치는 영향

6 From Firm-level Imports to Aggregate Productivity: Evidence from Korean Manufacturing Firms Data

7 자유무역협정(FTA)이 한국 기업의 기업내 무역에 미친 효과

8 The Relation Between Monetary and Macroprudential Policy

9 조세피난처 투자자가 투자 기업 및 주식 시장에 미치는 영향

10 주택실거래 자료를 이용한 주택부문 거시 건전성 정책 효과 분석

11 Does Intra-Regional Trade Matter in Regional Stock Markets?: New Evidence from Asia-Pacific Region

Liability, Information, and Anti-fraud Investment in a Layered Retail Payment Structure

13 Testing the Labor Market Dualism in Korea

14 북한 이중경제 사회계정행렬 추정을 통한 비공식부문 분석
Geun-Young Kim •

Hail Park •

Peter Tillmann

JaeBin Ahn •

Chang-Gui Park •

Chanho Park

Sangwon Suh .

Byung-Soo Koo

Jaebeom Kim •

Jung-Min Kim

정성엽

JaeBin Ahn •

Moon Jung Choi

전봉걸 · 김은숙 · 이주용

Jong Ku Kang

정호성·김순호

정호성·이지은

Sei-Wan Kim •

Moon Jung Choi

Kyoung-Soo Yoon -

Jooyong Jun

Sungyup Chung •

Sunyoung Jung

최지영 


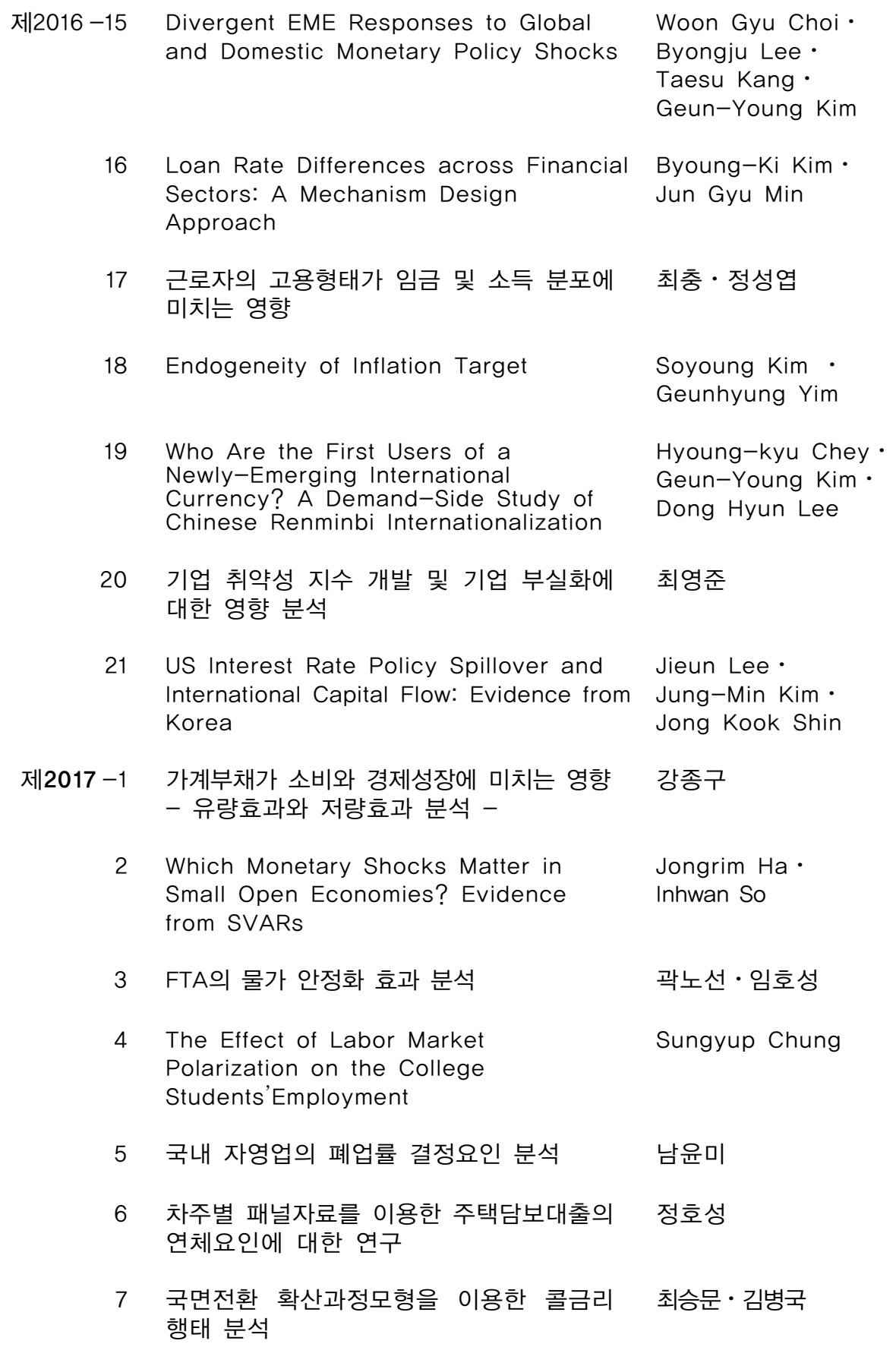




\begin{tabular}{|c|c|c|}
\hline 제2017 -8 & $\begin{array}{l}\text { Behavioral Aspects of Household } \\
\text { Portfolio Choice: Effects of Loss } \\
\text { Aversion on Life Insurance Uptake } \\
\text { and Savings }\end{array}$ & In Do Hwang \\
\hline 9 & 신용공급 충격이 재화별 소비에 미치는 영향 & 김광환 · 최석기 \\
\hline 10 & 유가가 손익분기인플레이션에 미치는 영향 & 김진용·김준철·임형준 \\
\hline 11 & $\begin{array}{l}\text { 인구구조변화가 인플레이션의 장기 추세에 } \\
\text { 미치는 영향 }\end{array}$ & 강환구 \\
\hline 12 & $\begin{array}{l}\text { 종합적 상환여건을 반영한 과다부채 } \\
\text { 가계의 리스크 요인 분석 }\end{array}$ & 이동진·한진현 \\
\hline 13 & $\begin{array}{l}\text { Crowding out in a Dual Currency Regime? } \\
\text { Digital versus Fiat Currency }\end{array}$ & $\begin{array}{l}\text { KiHoon Hong } \cdot \\
\text { Kyounghoon Park } \\
\text { Jongmin } \mathrm{Yu}\end{array}$ \\
\hline 14 & $\begin{array}{l}\text { Improving Forecast Accuracy of } \\
\text { Financial Vulnerability: Partial Least } \\
\text { Squares Factor Model Approach }\end{array}$ & $\begin{array}{l}\text { Hyeongwoo Kim } \\
\text { Kyunghwan Ko }\end{array}$ \\
\hline
\end{tabular}

